\title{
Do children of the first marriage deter divorce?
}

\author{
Héctor Bellido*, José Alberto Molina ${ }^{\dagger}$, Anne Solaz ${ }^{\ddagger}$ and Elena Stancanelli ${ }^{\S, * *}$
}

\begin{abstract}
In terms of economics, individuals divorce if their expected gains from marriage fall short of their expected utility outside the current marriage, and children represent a marriage-specific type of investment, which generally increases the value of marriage for the spouses. However, children may also disrupt marital stability as they will induce dramatic changes into the household allocation of money and time. In particular, children conceived before or after first marriage may be valued differently by the spouses and this may lead to marital conflicts. It is difficult to assign a priori the direction of the effect of children on marriage stability, and causality may run either way, as couples who anticipate a separation are more likely to have fewer children than those who are happy together, while children born before first marriage may be associated with a lower marriage attachment of their parents. Here, we follow an empirical approach and take advantage of the richness of the data on pre-marital history from the 24 waves of the National Longitudinal Survey of Youth79, to estimate the effect of children conceived before or after first marriage on marital stability. We find a significant deterrent effect of young children conceived during first marriage to the likelihood of divorce, while children conceived before first marriage are found to have a disruptive effect on marital stability.
\end{abstract}

Keywords: Children, Divorce, Family economics

JEL: J12, J13, J19

\footnotetext{
*Corresponding author. Facultad de Economía y Empresa, Universidad de Zaragoza Gran Vía 2, 50005 Zaragoza (Spain); Tlfn.: (34) 976761000 Ext. 4621; E-mail: hbellido10@gmail.com

${ }^{\dagger}$ University of Zaragoza and Institute for the Study of Labor (IZA).

*Institut National d'Études Démographiques (INED).

$\S$ Paris School of Economics, CNRS, Centre d'Économie de la Sorbonne, and IZA.

** The authors thank the Journal Editor, Professor Sushanta Mallick, and two anonymous referees for their helpful and constructive comments. The authors are grateful for financial support from the Science, Technology and University Department of the Government of Aragon (grant reference number B094/09), and the Spanish Ministry of Economics (Project ECO2012-34828) as well as the Institut National d'Études Démographiques (INED). This paper was partially written while Elena Stancanelli was visiting the University of Zaragoza, and while José Alberto Molina was Visiting Fellow at the Department of Economics of Boston College, whose support is gratefully acknowledged. The usual disclaimer applies. The authors bear sole responsibility for the analysis and the conclusions presented in this article.
} 


\section{Introduction}

In spite of the trend towards falling divorce rates in the U.S (see Figure 1), currently about one of every five white Americans has gone through a divorce. Among the determinants of divorce, the presence of children has attracted considerable attention in the economic literature (Stevenson and Wolfers 2006; 2007; Svarer and Verner 2008; Vuri 2001; Waite and Lillard 1993). According to the mainstream economic models, an individual decides to marry if the expected gains (emotional, monetary, and other) from marriage exceed the gains of remaining single. Children are generally thought of as making marriage more valuable to the spouses, as they represent a long-term commitment (that can be seen also as a form of long-term investment in the marriage relationship) which may reinforce marriage stability. On the other hand, children may bring about marital conflict by affecting dramatically the household allocation of time and money and contributing a degree of uncertainty, as children's preferences and behavior are not known to parents ex-ante. Children can be seen as a 'public' household good that both spouses enjoy, but they may also be seen as competitors for scarce time and money resources (Del Bono et al. 2012) and in this respect could be a hindrance to marital stability. Children conceived outside marriage may have different preferences and behaviors than those conceived after the couple married, as for example, they may have experienced some hardship at an early stage of their life, or they may be hostile to the (step) parent, if they come from an earlier relationship. In particular, children conceived before first marriage may also be valued differently by the spouses and this may bring about marital conflict. The aim of our study is to provide new empirical evidence of these relationships by exploiting the richness of information collected by the NLSY79. 
The relationship between children and marriage stability is crucial, as most policy makers in OECD countries aim to increase population fertility rates, to counter population ageing. ${ }^{1}$ However, if the presence of children is viewed as an obstacle to marriage stability, the costs for society may be high, as the costs of divorce for divorcees and for their children have been widely documented (Amato 2004; Smock $1993 ; 1994)$.

Let us stress that the spouses' 'value' of marriage is not exogenous to the decision to have children. Happier couples are more likely to have children, and the timing of children, before or after marriage, may also depend on spousal attitudes to marriage and cohabitation, which may in turn affect their propensity to separate. Thus, we adopt an instrumental variable and panel data approach to study the relationship between children conceived before and after the first marriage, and the risk of marital disruption. We exploit the extensive information on the pre- and post-marital history of a sample of American youth collected by the National Longitudinal Survey of Youth 1979 (NLSY79), of which twenty-four waves are currently available. ${ }^{2}$ Since we can observe the same individual (the same couple) many times, we can control for individual unobserved heterogeneity in our model. Because the number of children conceived before or after first marriage may not be independent of individual propensity to divorce, we take an instrumental variable approach. We instrument the number of children conceived during first marriage with the number of siblings of the respondent (as we expect that individuals who grow up in larger families may be more likely to have more children (Booth and Kee 2006)) and, alternatively, with multiple births, that

\footnotetext{
${ }^{1}$ See, for instance, Bielecki et al. (2015) for an analysis of the role of pension reforms under different scenarios of decreasing fertility and increasing longevity. Alders (2005) studies the effects of exogenous fertility shocks on human capital accumulation and the rate of obsolescence of older workers. Fanti and Spataro (2013) investigate the relationship between public debt and fertility. Lau (2014) analyzes the economic consequences of fertility and mortality changes by incorporating realistic demographic features into a continuous-time overlapping-generations model, with childhood, adulthood and retirement stages.

${ }^{2}$ Rotz (2011) uses similar data to investigate the determinants of declining divorce rates in the U.S.
} 
represent a somewhat exogenous increase in family size (Rosenzweig and Wolpin 1980). We find that children conceived during first marriage dramatically reduce the risk of marital dissolution. The chances of divorce decline with each additional child by 0.19 on average, which is a sizable effect. ${ }^{3}$ Moreover, we find that the presence of children conceived before first marriage, instrumented with the age at first intercourse, has a positive effect on divorce, though smaller in size (about half) than the protective effect of children conceived within marriage.

The remainder of this paper is structured as follows. Section 2 presents the background theory, and Section 3, the empirical strategy. In Section 4, we describe the data and the sample selection. The results of estimations are presented in Section 5, and conclusions are drawn in Section 6.

\section{The theoretical set-up}

The economic model of marriage predicts that individuals marry if the expected value of being married exceeds that of remaining single and there is a marriage surplus that spouses will share and benefit from. Marriage separation will occur when, due to (unexpected) shocks, the value of being married drops below that of separation for either one or both spouses (depending on whether unilateral divorce is available, and more generally, on the divorce laws). Economic models of marriage and divorce focus on the 'value' of marriage. Individuals marry because there are gains from marriage. Such gains may be emotional, like love and affection, as well as economic, such as sharing economic and time resources together (Grossbard-Shechtman 1993; 2003).

Formally, to model the individual decision to separate, we must model the individual value function of being married to the current spouse $\left(\mathrm{V}_{\mathrm{m}}\right)$, and of separating

\footnotetext{
${ }^{3}$ The divorce rate is about 0.37 in our dataset, where more than one of every three marriages ends in divorce. A similar divorce rate for first marriages, equal to $34 \%$, is recorded by Waite and Lillard (1993) for the PSID sample.
} 
from them $\left(V_{s}\right)$, which depend on the utility of consumption and on an uncertainty term (which may also capture random shocks or tastes) under the two states of marriage and separation, while being subject to budget and time constraints. Thus, we first express:

$$
\mathrm{V}_{\mathrm{mj}}\left(\mathrm{C}_{\mathrm{mj}}, \mathrm{C}_{\mathrm{m}}, \mathrm{H}_{\mathrm{m}}, \mathrm{u}_{\mathrm{m}}\right) \text { with } \mathrm{j}=\mathrm{h}, \mathrm{w} \text { denoting the two spouses }
$$

considering that $\mathrm{H}_{\mathrm{m}}=\mathrm{f}\left(\mathrm{z}, \mathrm{t}_{\text {junpaid }}\right)$ denotes the output of household production, $\mathrm{t}_{\text {jpaid }}+\mathrm{t}_{\text {junpaid }}+\mathrm{t}_{\text {jleisure }}=\mathrm{T}$ indicates each spouse's time constraint, and $\mathrm{t}_{\mathrm{hpaid}} * \mathrm{~W}_{\mathrm{h}}+\mathrm{t}_{\mathrm{wpaid}} * \mathrm{~W}_{\mathrm{w}}+\mathrm{Ynl}_{\mathrm{h}}+\mathrm{Ynl}_{\mathrm{w}}=\mathrm{C}_{\mathrm{mh}}+\mathrm{C}_{\mathrm{mw}}+\mathrm{pz}+\mathrm{C}_{\mathrm{m}}$, is the household budget constraint. Similarly, we express:

$$
\mathrm{V}_{\mathrm{sj}}\left(\mathrm{C}_{\mathrm{sj}}, \mathrm{C}_{\mathrm{s}}, \mathrm{H}_{\mathrm{s}}, \mathrm{u}_{\mathrm{s}}\right)
$$

with $\mathrm{H}_{\mathrm{s}}=\mathrm{f}\left(\mathrm{z}, \mathrm{t}_{\text {junpaid }}\right), \mathrm{t}_{\text {jpaid }}+\mathrm{t}_{\text {junpaid }}+\mathrm{t}_{\mathrm{jleisure}}=\mathrm{T}$, and $\mathrm{t}_{\mathrm{jpaid}} * \mathrm{~W}_{\mathrm{j}}+\mathrm{Ynl}_{\mathrm{j}}=\mathrm{C}_{\mathrm{sj}}+\mathrm{C}_{\mathrm{s}}$.

The subscript $m$ denotes the state of being married and $s$ that of separation, and $C_{j}$ represents private consumption, respectively in each of the two states $\mathrm{m}$ and $\mathrm{s}$ for each spouse $\mathrm{j}$; $\mathrm{C}$ denotes public consumption (including expenditure incurred for children) and $\mathrm{H}$ is the output of the household production function (which also includes children, as well as home goods and services produced for children). As is conventional in household economic models, the output of household production is hard to measure but it is produced by combining goods $\mathrm{z}$ purchased from the market (at prices $\mathrm{p}$ ), and spouses' unpaid work time, $\mathrm{t}_{\text {junpaid. }}$ The output of household work may be consumed either privately (for example, a cup of coffee) or publicly (for example, a clean house). The typical characteristic of a public good is that it can be enjoyed (or disliked) by more than one person, such as, for example, a painting in the living room that one spouse adores and the other can barely tolerate - as opposed to eating an apple, which is deemed to be private consumption. The uncertainty term varies across the two states of the world for each spouse. For example, married individuals may be uncertain about the own or the spousal future health status, or may not be able to anticipate how they will 
get on with their step-children, and so forth. Unmarried separated individuals may be uncertain about whether they will meet a new marriageable partner, or whether their children may suffer from the parental separation, and so on. The importance of uncertainty in determining the individual expected value of marriage relative to the value of being single (or the external options) has received considerable attention since the pioneering work of Becker et al. (1977). It should, perhaps, be added that the value of marriage for each spouse may well differ from the sum of the value of being single for each spouse, as marriage will generate certain extra surplus for the spouses, such as love, caring, children, or in the form of the output of household production, if there are technology gains to being married, and possibly also increasing economies of scale. Marriage may also generate some negative losses for one or both spouses, for example, in the event of one of the spouses becoming disabled or losing their job, or due to changes in the divorce or child custody laws. According to the economic model, individuals will separate if the expected value of marriage $\left(E\left(V_{j m}\right)\right)$ falls short of the expected value of being single $\left(\mathrm{E}\left(\mathrm{V}_{\mathrm{sj}}\right)\right)$.

According to Becker's model of the family (Becker 1981), children represent a marriage-specific investment, whose value is positively correlated with parental education (Black et al. 2005; Currie and Moretti 2003), which may contribute to making marriage more valuable to both spouses and thus, more stable. Children conceived before first marriage may have a different value for the spouses - for example, if one is a step-parent. Generally, the presence of children is likely to introduce a degree of uncertainty in the marital relationship, as for example, it is hard to anticipate whether the child will wake up often at night, or will fall sick on a certain day, or what their school grades will be, and parents may disagree on how to deal with these events. Children have their own preferences, which are usually unknown to the future parents, 
and if parents care for their children, this fact alone may bring considerable uncertainty into the household allocation of time and money (i.e. private expenditure). Del Bono et al. (2012) show that parental behavior is substantially affected by the arrival of children. Parents may disagree on the children's upbringing, which may lead to marital conflict (Svarer and Verner 2008; Vuri 2001; 2002), while the amount of leisure time that partners spend together often dramatically falls in couples with young children, making the marital relationship more fragile (Barnet-Verzat et al. 2011; Beblo 1999).

In household economic models, children are considered as public goods (Friedberg and Stern 2003), a good that both parents enjoy. ${ }^{4}$ But children also affect the household decision-making and consumption, either directly (if they are viewed as having their own utility function that enters the household utility function) or indirectly, via the parents' utility function. Spouses' gains from marriage depend on spouses' time allocation and consumption, which are both dramatically affected by the presence of children. Parents may disagree on how to allocate time and money to children. The presence of children is going to affect home production $(\mathrm{H})$, as well as public $(\mathrm{C})$ and private consumption $\left(\mathrm{C}_{\mathrm{j}}\right)$ and the spouses' allocation to paid ( $\left.\mathrm{t}_{\text {paid }}\right)$ and unpaid work $\left(t_{\text {unpaid }}\right)$. Children conceived before marriage may have different preferences and behave differently than those conceived after their parents married, for example, if they have experienced some hardship at an early stage of their life, or if they are resentful of their (step) parent. Finally, the presence of children may also change the spouses' 'outside options', as parents will meet new people through their children such as doctors, babysitters, school teachers, as well as other parents, and so forth, and this may add to marriage instability.

\footnotetext{
${ }^{4}$ Other examples of public goods in household economic models are the home, heating, painting and decorating the living room wall. An example of private goods is the clothes consumed by each spouse.
} 
Since marital stability and the presence and number of (young) children are generally positively associated, it is difficult to disentangle the direction of causality when studying the relationship between the number and age of children and parental divorce. ${ }^{5}$ Cultural and social norms may also affect both fertility decisions and marriage stability (Furtado et al. 2013; Sevilla-Sanz 2010).

Earlier studies conclude that children have a protective effect on marriage, especially when they are young (Andersson 1997; Cherlin 1977). However, other authors, addressing the potential endogeneity of fertility in a marital stability model, come to mixed conclusions. For example, Koo and Janowitz (1983) conclude that the effect of fertility on divorce is insignificant. In contrast, Waite and Lillard (1993), using PSID data and modeling simultaneously the duration of marriage and the elapsed time before childbirth, find that the first child contributes positively to marital stability, whereas subsequent children have a negative effect. Steele et al. (2005) conclude that young children positively affect marital stability. Vuri (2001) instruments fertility with the gender of the first two children, finding that children have a negative impact on marital stability. Vuri (2002) also concludes that the sign of the relationship varies with the age of the child, with younger children having a positive effect on marital stability, and older ones a negative effect, in line with the argument that parents postpone divorce until the children are older. Svarer and Verner (2008), using census data for Denmark, estimate a bivariate duration model of marriage survival and time intervals to childbirth, showing that the presence of children increases the risk of marital disruption, and especially so for the first and second children. Therefore, the earlier literature comes to controversial conclusions on the direction of the effect of the number and the age of children on marital disruption.

\footnotetext{
${ }^{5}$ Couples who anticipate divorce are less likely to have children (Myers 1997).
} 
The literature is much less prolific on the effect of children conceived outside marriage on the stability of marriage. Earlier studies conclude that children born out-ofwedlock, or from cohabiting parents, experience higher parental separation rates on average, even when those parents subsequently marry (Manning et al. 2004; Osborne et al. 2007). Lunberg and Rose (2003) find that the gender of the first child affects the marriage probability of mothers (of children born out-of-wedlock), which suggests that boys make marriage more valuable for fathers. Dahl and Moretti (2008) conclude that when the first child is a girl, mothers are less likely to marry; shotgun marriages are less likely to take place, while married parents are more likely to divorce. However, they also find that the number of children is considerably higher in families with first-born girls. The compositional effects of out-of-the-wedlock births in relation to increasing cohabitation trends in the U.S. are thoroughly investigated by Ermish (2009).

In our sample of married youth, sixty percent of the couples conceived their children after marriage, while forty per cent did so before that event. ${ }^{6}$ Therefore, it seems unlikely that children conceived before marriage by parents who subsequently married were all 'unplanned' births. While the vast majority of couples wait to marry before having children, there is a sizable number of couples who only marry after having conceived a child. Since formal marriage requires a stronger commitment than cohabitation, expecting a baby may be the key fact that convinces the couple to make a stronger commitment and marry. Under this scenario, children born outside marriage may consolidate the union. On the other hand, if the children conceived before first marriage come from an earlier, different union, their presence may hinder marriage stability and lead to conflict, as the blood-parent and the step-parent may value them

\footnotetext{
${ }^{6}$ This is in line with Lundberg and Pollak (2013) who show that cohabitation has become more and more common in the Unites States in recent times.
} 
differently. ${ }^{7}$ Moreover, the non-residential parent of children born out-of-the-wedlock from an earlier union also tend to contribute to child upbringing and have their say (Ermish 2008; Ermisch and Pronzato 2008), which may add to marital conflict between the natural parent and the step-parent of the current union (our unit of observation).

Here again, causality may run either way, as individuals who had children out-ofwedlock (before first marriage) may be more likely to divorce (see, for a discussion, Waite and Lillard 1993). ${ }^{8}$ For example, they may value formal marriage less, or may not see children as a marriage-specific investment. Therefore, it is difficult to sign a priori the effect of children on marital stability and our approach will therefore be empirical. To disentangle causality from statistical correlation, we take an instrumental variable and panel data approach.

\section{The empirical model}

According to economic models of marriage and divorce, it is difficult to sign a priori the effect of the presence of children on marriage stability, and this may vary with the number, gender, and age of the child. Children conceived before and after first marriage may also have a different effect. Here we take an empirical approach, and specify a reduced-form model of the effect of children on the couple's probability of divorce. Formally, let us assume that children conceived before or within first marriage linearly affect divorce as follows:

$$
\text { Divorce }_{i t+1}=\beta_{1} \text { Children-within }_{i t}+\beta_{2} \text { Children-before }_{i t}+\beta_{3} X_{i t}+\alpha_{i}+\varepsilon_{i t}
$$

\footnotetext{
${ }^{7}$ Children born during cohabitation to couples who marry later may be valued as marriage-specific investments. We do not attempt here to model all these different categories of children and couples, but we control for coupleunobserved effects in the model.

${ }^{8}$ Although cohabitation before marriage has become more common among younger U.S. generations (Lundberg and Pollak 2013), we do not model cohabitation here, as this is not an exogenous decision. We control for individual unobserved heterogeneity, which will also capture individual preferences for cohabitation before marriage, knowing that our sample only includes individuals at risk of divorce (see Data Section).
} 
where Divorce ${ }_{i t+1}$ is a dummy variable that takes value 1 if individual $i$ divorces (or separates) in year $t+1$. Children-within ${ }_{\text {it }}$ represents the number of children conceived during first marriage by individual $i$ up to year $t$, Children-before ${ }_{i t}$ is the number of children conceived before first marriage, and $\mathrm{X}_{\mathrm{it}}$ is a vector of individual characteristics measured at time t, such as age, gender, race, charges of illegal activity during youth, presence of the respondent's father during youth, own and partner's level of education, controls for age differences between spouses, and region of residence. The errors of the equation contain a constant $\alpha_{i}$ that captures individual unobserved heterogeneity (such as negative attributes that would make someone a less attractive long-term partner), and an error term, $\varepsilon_{i t}$, which is assumed to be normally distributed. Since we control for the number of children and individual characteristics in year $t$, one year before recording the event of divorce (or separation), the covariates can be seen as 'pre-determined' with respect to the decision of marital disruption. Moreover, to account for the potential endogeneity (the fact that children may affect divorce, but divorce in turn also has an impact on the number of children conceived within first marriage), and to disentangle the direction of causality, we instrument the number of children with a series of variables related to the respondent's youth. We also control for individual unobserved heterogeneity by exploiting the repeated observations for the same individual in our data, as respondents were interviewed many times over several years. Thus, we specify an instrumental variable and panel data model as follows:

$$
\begin{gathered}
\text { Divorce }_{\mathrm{it}+1}=\gamma_{1} \text { Children-within }_{\mathrm{it}}+\gamma_{2} \text { Children-before }_{\mathrm{it}}+\gamma_{3} \mathrm{X}_{\mathrm{it}}+\lambda_{\mathrm{it}} \\
\text { Children-within }_{\mathrm{it}}=\theta_{1} \text { IV-within }_{\mathrm{it}}+\theta_{2} \mathrm{X}_{\mathrm{it}}+\mu_{\mathrm{it}} \\
\text { Children-before }_{\mathrm{it}}=\theta_{3} \text { IV-before }_{\mathrm{it}}+\theta_{4} \mathrm{X}_{\mathrm{it}}+\xi_{\mathrm{it}}
\end{gathered}
$$

where IV stands for the instruments, which are correlated with the potentially endogenous variable, and exogenous with respect to the dependent variable in Eq. (4). 
The errors can be decomposed into an individual specific effect and a normallydistributed error term (as in Eq. (3) above). ${ }^{9}$

\subsection{Identification}

We here discuss the choice of instruments, and in the following section we report the results of formally testing their validity. We take an instrumental variable approach since causality may run both ways, as children may affect marital stability, but happier couples are also more likely to have children. Therefore, we instrument children with variables that we expect to affect the number of children but not the probability of marriage break up.

In particular, we instrument the number of children conceived before and within first marriage with a series of variables related to the respondent's background, as follows. We use information on the number of siblings of the individual, and construct a series of dummies, respectively, for one, two, three, and four or more siblings (the reference group is individuals with no siblings). Individuals are likely to replicate the fertility behavior of their parents (as documented, for example, in Axinn et al. 1994; Booth and Kee 2006). ${ }^{10}$ We also use multiple births as instrument, measured by a dummy variable that takes value 1 if the respondent had twins, triplets, or more during first marriage (Cáceres-Delpiano 2012). We expect the presence of an unplanned child (as a consequence of the multiple birth) to be exogenous to the probability of marital disruption (Jacobsen et al. 2001), since individuals may not be able to fully anticipate their chances of having a multiple birth. ${ }^{11}$ Moreover, we include a series of dummies for

\footnotetext{
${ }^{9}$ Wherever possible, we check our results by including robust standard errors in our model, finding no significant differences from our main specification.

${ }^{10}$ Larger families are often associated with lower divorce rates, so that having more siblings could also capture the fact that the respondent grew up in an intact family. Under this scenario, the number of siblings would affect directly and negatively the chances of divorce. To distinguish the direct effect of siblings on the divorce rate from the indirect effect of siblings, the latter via children, we checked whether the number of siblings affected the respondent's divorce rate in childless couples, and found no effect.

${ }^{11}$ We tested whether multiple births affect directly the respondent's divorce rate, and we found no significant effect.
} 
the respondent's age at first sexual intercourse. ${ }^{12} \mathrm{We}$ account for whether interviewees had intimate relations before turning 16 years old, or between 16 and 18 years old, or after 18 (the reference group are individuals who had no intimate relation by the years 1983-1985, when respondents were between 21 and 28 years old). We expect age at first intercourse to affect the probability that respondents have children before first marriage (Miller and Heaton 1991). According to other sources, the mean age of first intercourse after menarche for women aged 15-44 was 17.4 in 2002, and for men aged 15-44 was 17.0, also in 2002 (Chandra et al. 2005; Martínez et al. 2006).

\section{Data}

We use data drawn from the American National Longitudinal Survey of Youth 1979 (NLSY79) to estimate the model. This survey began in 1979 , by sampling 12,686 individuals born between 1957 and 1965 (aged between 14 and 22 in 1979), who were interviewed each following year until 1994, and every two years (in even-numbered years) since 1994, thus producing 24 waves to date. Detailed information was collected on individual family background, intimate relations, charges of illegal activities during youth, (pre)marital fertility, education, and labor market experience, as well as partner's characteristics. We selected the sample of individuals for the analysis as follows:

1. They married at some stage during the survey period.

2. They were at least 21 years old when they married. We drop early marriages, for which the timing of marriage may not be independent of the individual schooling level. However, for sensitivity purposes, we also experiment by including all first marriages in the sample, regardless of the age of the respondent at marriage.

\footnotetext{
${ }^{12}$ Although this instrument may correlate with other unobservable individual characteristics that also affect divorce chances, we also control in our model for individual unobserved effects, thanks to the fact that we can observe the same individual over time.
} 
3. We dropped higher order marriages (second, third...) from the analysis, as well as those few marriages that ended with the death of the spouse during the sample period.

Our sample includes 5,574 individuals in their first marriage. Our dependent variable is a dichotomous indicator of whether the individual is (still) married, or divorced (or separated) at time $\mathrm{t}+1$. The event of marital dissolution is defined as reporting being separated or divorced, as for example in Chan and Halpin (2002).

The covariates are measured one year earlier, at time t. We know the month and year in which children were born, and the year and month of first marriage, so we can distinguish between children conceived before and during first marriage. We assume that children born before or during the first 8 months of the first marriage were conceived before marriage. It seems more likely that the pregnancy had already begun when the couple married than that the wife became immediately pregnant in the first month of marriage. However, for robustness purposes, we also re-estimate the main model, dropping from the sample individuals who gave birth in the first eight months of marriage, finding that our conclusions are unaffected.

Table 1 presents descriptive statistics for the main sample. In Table 2, we split the sample between divorcees and individuals in intact first marriages, providing more descriptive statistics. Considering that individuals are repeatedly observed during their marriage, and only once when they are divorced, the proportion of first marriages ending in divorce during the survey period in our sample reaches $37 \%$, that is to say, more than one in every three marriages ends in divorce. On average, respondents conceived one child during first marriage, while roughly $15 \%$ of the sample had (already) conceived a child before marriage. The mean age at first marriage of those 
who later divorce is 24.5 years (Table 2), and the mean age at divorce is almost 32 years, implying an average duration of first marriage of six to seven years.

About $77 \%$ of the respondents are married to someone of the same age. In contrast, the husband is more than five years older than the wife in $19 \%$ of the cases. Almost $25 \%$ of the sample has a college degree; over $31 \%$ have more than college education, while less than $7 \%$ have less than high school (less than intermediate education). Blacks account for $19 \%$ of the sample and Hispanics for $16 \%$. As for geographical location, we distinguish four regions: North East (the reference category), North Central, South, and West. ${ }^{13}$ Finally, $7 \%$ of the survey participants in our sample were charged with some illegal activity in youth, within the first two years of the survey.

For the subsample of intact marriages, the average age at first marriage is very similar to the main sample and equals 25.1 years. Individuals in an intact marriage had on average 0.42 more children conceived during first marriage than those whose marriage ended, although this may simply be due to the fact that we observe them longer, as they did not divorce during the sample period (see Table 2). This evidence confirms the importance of allowing for the endogeneity of children in the model. Both the own and the partner's level of education are on average higher for individuals in intact marriages than for divorcees. Individuals whose father was not in the household in 1979 are more represented among those who later divorce, than among those in intact marriages. The proportion of blacks is 10 percentage points higher among those who experienced marital disruption than among stable first marriages. These discrepancies reinforce the need to control for socio-demographic characteristics among the determinants of marriage instability.

\footnotetext{
13 "The Bureau of Labor Statistics (BLS) only grants access to geocode files for researchers in the United States", as stated by the BLS survey documentation. See, for example, Bellido and Marcén (2014), Cáceres-Delpiano and Giolito (2008), Friedberg (1998) and Wolfers (2006) on the relation between regional divorce laws and social outcomes, such as divorce rates or fertility rates. See Appendix, Table A, for definitions of the variables used.
} 


\section{Results}

Children conceived before or after first marriage may have a different impact on marriage stability (see Section 3). It is difficult to sign a priori the direction of this effect. Besides, couples who anticipate their separation are likely to have fewer children than those who are happy together, while those who value marriage less may be more likely to conceive children out of marriage. Thus, in an effort to measure a causal effect, we adopt an instrumental variable approach and take advantage of the wealth of premarital information collected by the NLSY79 to single out identifying variables that may affect the couple's number of children but not their propensity to divorce. The latter is the requirement for valid instruments, and it is met overall by our specification (see discussion below). We instrument the number of children conceived before or during first marriage by exploiting alternative sets of instruments (see Section 3 for discussion): a series of dummies accounting for the number of siblings of the respondents, controls for the occurrence of a multiple birth, and a series of dummies indicating whether interviewees had their first intercourse before turning age 16, or between 16 and 18, or after age 18 (the reference group are individuals who had no intimate relations by the years 1983-1985, when respondents were between 21 and 28 years old). We also exploit the fact that the same couple is observed many times in our data, to control for couple-unobserved heterogeneity, i.e. unobservable individual characteristics that may make someone more or less likely to be marriageable (such as beauty, for example, which is not recorded in the data).

\subsection{Results of estimation of the main model: instruments validity}

The results of our estimation of the main model are given in Table 3, specification (1), in which the number of children conceived before and within marriage are instrumented using all the instruments, and we also control for individual unobserved heterogeneity. 
Let us first of all discuss instruments validity, which relies on the instruments having a significant effect on the endogenous variables (the number of children conceived before or after marrying) but not having a direct impact on the couple's propensity to break up.

The first stage regressions for the number of children conceived before and within marriage include all the instruments, as well as all the explanatory variables of the model (the later coefficients are not shown in Table 3 for the sake of readability).

Perhaps not surprisingly, we find that multiple births have a significant and positive effect on the number of children conceived during first marriage, as well as on the number of children conceived before first marriage. Therefore, multiple births is a good instrument for the number of children, but does not allow us to identify children conceived within marriage from children conceived before marriage. As far as the number of siblings of the respondent goes, all the dummies for, respectively, one, two, three, and four or more siblings have a significant and positive effect on children conceived before marriage, while only having at least four siblings affects the number of children conceived after marriage. This result is unexpected, and it may suggest that individuals coming from larger families are perhaps more likely to commit to marriage once they have had children. Coming to the effect of the dummies for respondent's age at first intercourse, we conclude that the younger the respondent at first intercourse, the more likely they are to conceive children before marrying, as expected. In contrast, the same dummies have a significant and negative effect on the number of children conceived after marriage, suggesting that individuals who had intimate relations before age 18 are less likely to have children within marriage. Therefore, our instruments do not go entirely in the direction we had anticipated, but all of them significantly affect children conceived either before or after marriage, so that overall we can achieve 
identification by using all these instruments, and the model passes standard overidentification tests (see below).

We tested for the validity of the instruments by running a Sargan-Hansen test (Baum et al. 2007), which is based on running a regression of the residuals from the instrumental variable model on all the instruments, and has a chi-square distribution under the null hypothesis of no correlation between the errors of the instrumental variable model and all the instruments used. A strong rejection of the null hypothesis would invalidate the instruments chosen. The advantage of this test is that it can also be run with panel data, and it is especially suited to a large set of instruments, as in the case of our model, as it detects possible overidentification (known also as "weak instruments") problems (Baum et al. 2007). For our preferred specification (Table 3), the test statistic is distributed as a chi-square with 6 degrees of freedom and it is equal to 7.677 (with a p-value of 0.2628). Therefore, we cannot reject the null hypothesis at the $5 \%$ statistical significance level, and our instrumental variable specification is validated by this test. Clustering the repeated observations by the person identification number, the test statistic is distributed as a chi-square with 6 degrees of freedom and it is equal to 9.768 (with a p-value of 0.1348 ) for our preferred specification (Table 3). Therefore, again we cannot reject the null hypothesis at the 5\% statistical significance level and our instrumental variable specification is again validated.

Moreover, to be valid, the instruments should not have a direct effect on divorce outcomes, but should only affect marriage stability via their effect on children. One may for example argue that individuals who grow up in larger families are also more likely to have grown up in intact families, and thus having experienced more siblings could have a direct and positive effect on the marriage stability of the respondent. To test for the possibility that the number of siblings of the respondent may also affect directly the 
respondent's marriage stability, we estimate the effect of siblings on divorce chances for couples who have not yet had children. By selecting childless couples, we can neatly isolate the direct effect of respondent's siblings on the couples' divorce chances. If larger families with more siblings were associated with more stable marriages, and if individuals coming from such marriages would replicate the same behaviour as their parents, and are less likely to divorce, then we would find a negative and significant effect of the number of siblings on divorce chances, with the same holding true for respondents who have not yet had children. However, selecting childless couples from our sample of married couples, we find no direct effect of siblings on the respondent's divorce probability. If we include also couples with a positive number of children in the sample, we find that siblings have a negative and significant coefficient on the divorce probability equation, but we argue that this may well be an indirect effect (since siblings affect respondent's fertility, they will affect divorce via their effect on the couple's number of children). Since there is no effect of siblings on the divorce rates of respondents who have not yet had children (childless couples), our argument is supported. Therefore, we believe that siblings satisfy the exclusion restriction condition and are a valid instrument.

On multiple births, we test whether this variable directly affects the divorce chances of the respondent, and we find no significant effect. Given that the instrument is only available for respondents with children, here we keep all the couples in the estimation sample. Moreover, we find a significant and positive effect of multiple births on the couple's number of children, as anticipated (Table 3). We conclude that this instrument also meets the validity requirement, since it does not affect the outcome variable (divorce), but does affect the endogenous variable in the model (number of children). 
With respect to age at first intercourse, we run this basic test of exclusion restrictions, and find a direct and positive effect on couple break-up rates, as individuals who are more sexually active may be at greater risk of having an unstable marriage. However, in our data, the individual age at first intercourse has significant effects, and in opposite directions, on children conceived before or after the couple married (Table 3). Once these variables are directly included in the divorce model, together with the instruments, the direct effect of age at first intercourse on the probability of divorce becomes statistically non-significant.

As an additional robustness check, we re-estimate the model dropping age at first intercourse from the set of instruments, and recalculate the Sargan-Hansen test statistic, which is now distributed as a chi-square with 3 degrees of freedom and is equal to 3.236 (with a p-value of 0.3566 ). Therefore, we cannot reject the null hypothesis at the $5 \%$ statistical significance level. We conclude that, using this restricted set of instruments, the instrumental variable specification is also validated by this test. Let us add that the instruments are also significant in the first stage regressions, as required for valid instruments. However, under this specification, which only relies on siblings and multiple births to identify the effect of children conceived either before or after first marriage on divorce, we find that either category of child has a negative and statistically not significant effect on spousal divorce.

In contrast, including only the dummies for age at first intercourse as instruments, the Sargan-Hansen test takes the value 0.098 and is distributed as a chi-square with one degree of freedom (the p-value is 0.7543 ); thus, the model is still identified and passes this test. The dummies for age at first intercourse affect significantly and positively (negatively) the number of children conceived before (after) marriage, and we find that children conceived before first marriage have a strongly significant and negative effect 
on marriage stability, but those conceived after marriage have a negative and not significant effect. We then re-estimate this model variant (using only the set of age at first intercourse dummies as instruments), allowing only children conceived after first marriage to affect the divorce probability (not considering children conceived before marriage) and we find a strongly significant and negative effect on parental divorce probability (the estimated coefficient is equal to -0.50). This model also passes the Sargan-Hansen test and the instruments affect significantly and negatively the number of children conceived after first marriage. Alternatively, instrumenting only children conceived before first marriage with the set of age at first intercourse dummies, we find a strongly significant and positive effect on divorce chances (the estimated coefficient is equal to 0.15). This model also passes the Sargan-Hansen test and the instruments affect significantly and positively the number of children conceived before first marriage.

Finally, we test for the robustness of our estimations by including some of these instruments separately in regressions (see Tables 11 and 12, and later in this Section 5, for an extensive discussion), and our main conclusion that children conceived before or within first marriage have opposite effects on marriage stability remains true, as long as we include the dummies for age at first intercourse in all such specifications.

To conclude, although instrumental variable models are generally considered as a second-best approach, in the absence of a natural experiment, it appears that our specification is reasonably robust.

\subsection{Results of estimation and heterogeneous effects by education,}

\section{gender, race and gender of the first child}

Results of estimation of the main model indicate that the number of children has a significant effect on marital stability (Table 3, Divorce Outcome equation), which goes in the opposite direction for children conceived before (negative) or after marriage 
(positive). An additional child after marriage reduces the chances of divorce by 0.192 , while an additional child before marriage increases those chances by 0.10 .

We also show in Table 3 the results of our estimation of similar models in which the number of children is not instrumented, but is treated as if it were a predetermined variable, exogenous to marriage breaks (specifications (2) and (3) of Table 3). In specification (2) we use random effects, while in specification (3) we specify individual fixed effects. These are alternative approaches to control for individual unobserved characteristics. Under both specifications, the effect of children conceived before marriage on divorce chances remains significantly positive, while the effect of children conceived within marriage remains negative and significant. However, these effects are much smaller in absolute value in specifications (2) and (3) than in the main model, in which we allow children to be determined endogenously.

To test for differential effects of the number of children on marital stability, depending on the education of the respondent, we stratify the sample by education, and re-estimate the model separately for each education group, distinguishing individuals with an intermediate education level (high school), from those with less (more) than high school (Table 4). Notice that the smallest group is that with less than high school education, for whom we find that children 'before' marriage have no significant effect on divorce rates; the estimated coefficient is, in fact, negative (though not significant), while children 'within' marriage significantly reduce the chances of divorce, with the effect being larger in absolute value than for higher-educated parents. For the other education groups, the estimates are very similar to those for the whole sample in terms of significance, sign, and size. Therefore, it would appear that for lesser educated individuals (if they are married at conception), children tend to have a slightly stronger marriage-stabilizing effect than for higher-educated couples. 
Splitting the sample by the gender of the respondent (Table 5), we find similar results to our main model (IV specification (1) of Table 3), though the protective (destructive) effect of children 'within' ('before') marriage is smaller in absolute value for men than for women. This could be due to the compositional effect (see descriptive Tables).

When splitting the results by respondent's race (Table 6), we find no effect of children conceived before marriage on the chances of divorce for blacks. Moreover, the disruptive effect of children conceived before first marriage is much smaller for Hispanics than for Whites and other races. Children conceived within first marriage have a significant and protective effect for blacks, but the effect is smaller in absolute value than for Hispanics, or Whites and other races. Overall, it appears that children affect the marriage stability of white respondents to a greater extent.

Finally, we consider the gender of the first child of the respondent, since prior studies point to the possibility that couples value differently the investment made when having the first child, depending on the child's gender (Dahl and Moretti 2008; Lundberg and Rose 2003). In Table 7, Column (1) presents the results of estimation of the model for couples whose first child is a boy (the reference group are childless couples) while Column (2) relates to couples whose first child is a girl (the reference group are childless couples). Our conclusions are not affected. Children conceived during first marriage have a protective effect on marriage stability regardless of their gender while children conceived before first marriage have a deterrent effect, regardless of their gender. Column (3) shows the results of estimation of the model when including only couples who have children at some point during the sample observation period, and controlling for the gender of the first child by means of an additional dummy. The latter does not show up significant, suggesting that in our set up -having distinguished 
children born before or after marriage- the gender of the first child does not affect marital stability.

\subsection{Results of estimations for different ages of children}

According to earlier studies (Vuri 2002), the deterrent effect of children on marital disruption is stronger when they are younger. At this point, we study the effect of children conceived before and within first marriage, depending on their age (Table 8).

The first subsample (column (1)) includes childless couples and couples with only children aged up to 2 years old, conceived before or within first marriage. Similarly, the second subsample (column (2)) is formed by childless couples, and couples with only

children conceived within or before first marriage aged 3-9 years old. The third subsample (column (3)) consists of childless couples, and couples with only children conceived within or before first marriage aged at least 10 years old.

Our results suggest that the older the children, the lower the deterrent effect on marital disruption of children conceived within marriage (in absolute value); and the lower the destabilizing effect of children conceived before marriage. We conclude that our results are in line with those of the prior literature (Vuri 2002).

\subsection{Robustness checks for the main specification}

Our main results are robust to various specification checks, such as dropping childless couples from the sample (Table 9), controlling for many additional covariates (Table 10), using only some subsets of the instruments (Tables 11 and 12), specifying probit models of divorce rather than linear probability models (Table 13), controlling for the presence of children rather than their specific number (Table 14), and including respondents of all ages at first marriage (Table 15). It should be remembered that our main sample only includes respondents aged at least 21 when they first marry. 
First, we re-estimate the model after dropping from the sample those respondents who did not conceive any children, at least not during the sample observation period (Table 9). Our main conclusions are not affected, though the absolute size of the estimated effect of the number of children conceived before and within first marriage on marital stability is now smaller and equal to about half its value in our main specification (IV Table 3).

Next, we carry out robustness checks for the inclusion of additional explanatory variables (see Table 10), that were excluded from our baseline model because of potential endogeneity concerns (these additional variables may be determined together with marriage duration). We begin by including in the regression a quadratic function of household income adjusted using the OECD equivalence scale, which assigns a weight of 1 to the respondent, a weight of 0.5 to each additional family member aged 14 or older, and a weight of 0.3 to each family member under age 14 (thus, for example, the income-scaling coefficient attributed to a two-parent family with two small children is 2.1). Results are shown in Specification (2) of Table 10, while Specification (1) again shows our baseline estimates (as in the IV model of Table 3). Since individuals who anticipate that their marriage may break up (Johnson and Skinner 1986) may adjust their labor market behavior in terms of both participation and hours supplied, family income is likely to be endogenous to the model, and so we do not include it in our preferred specification. We conclude that household income affects non-linearly the probability of marital disruption: as family income increases, the risk of divorce first decreases and then rises. This is somewhat in line with prior research that shows a negative effect of income on the risk of divorce (Burgess et al. 2003). The effect of the number of children conceived before (or within) first marriage on the risk of marital disruption remains 
positive (negative) and statistically significant and close in size to the estimates in our preferred specification.

Next, we add controls for the religious background of the respondent (Vaaler et al. 2009). Since religion establishes behaviors that are morally accepted, or rejected, if there is a process that jointly determines personal religious beliefs and the propensity to break up, then including controls for religious attitudes may bias our results. The results of the estimation are nevertheless robust to this check (Specification (3) of Table 10).

As an additional robustness test, we include a dummy indicating whether the respondent resides in an urban or a rural area. It may be endogenous to the model if the probability of living in a rural or an urban area is related to fertility behavior and marital breakup. Our estimate on the effect of the number of children conceived before or within first marriage on divorce is robust to this check (Specification (4) of Table 10). Living in an urban area has, as expected, a positive effect on the risk of marital disruption, but it is not statistically significant, perhaps because, as anticipated, it may be correlated with fertility.

We also control for both spouses' employment, which we do not include in our main model because anticipation of divorce may affect spouses' labor force participation (Johnson and Skinner 1986). The endogenous relationship between laborsupply and fertility is well documented, for example, in Angrist and Evans (1998). We find that both partners' employment actually reduces the probability of marital disruption. Again, the effect of children conceived before (or during) first marriage on the chances of divorce remains positive (negative) and statistically significant (Specification (5) of Table 10).

In Specification (6) of Table 10, we include all these additional controls simultaneously. The negative (positive) impact of children conceived within (before) 
first marriage on the risk of marriage break-up is comparable in size to that from our main specification (Specification (1) of Table 10), and remains statistically significant.

Our conclusions are robust to dropping siblings (Table 11) or multiple births (Table 12) from the set of instruments. In particular, the size of the estimates of interest remains very close to those of the main model (IV Table 3) when dropping siblings from the sets of instruments, but is much smaller when excluding multiple births. This is reasonable, since we show that multiple births have strong identification power, and while they significantly affect the number of children, they do not affect the chances of divorce of the respondents (Section 2).

In Table 13, we adopt a probit specification of divorce to check the robustness of our previous linear probability models. We find that each additional child conceived within marriage decreases the probability of divorce by $1.2 \%$, while each child conceived before marriage increases the risk of marital disruption by $0.7 \%$.

When modelling the presence of children (as a dummy that takes value 1 if the couple has a positive number of children, and zero otherwise) rather than the specific number of children, we find that our conclusions remain robust (Table 14).

Finally, we select a larger sample, which also includes respondents who married before turning age twenty-one, leading to a sample of 8,224 individuals (Table 15). Our results are not substantially affected, and the estimates of interest are close to those of our main specification. The effect of the remaining covariates on the probability of marital disruption is also very similar to the main specification.

\subsection{The effect of the other covariates on the main specification}

As for the other explanatory variables, we find an inverse U-shaped relationship between the age of the respondent and the risk of marital dissolution, according to specification (1) of Table 3. Our results also suggest that male respondents are just as 
likely to divorce as women. Divorce probabilities also increase with the age difference between the spouses (Table 3), but only when the husband is older. This is in line with the view that a significant age gap between the spouses captures marriage 'mismatch' (see, for example, Bloemen and Stancanelli 2015). In contrast, being charged with some illegal activity during youth significantly increases the individual chances of marriage break-up. In addition, we find that the older the individual at first marriage, the lower the probability of subsequent marital disruption.

\section{Conclusions}

We study the impact of children conceived before or within first marriage on marital stability, by exploiting the rich information on pre- and post-marital histories of the participants in the NLSY, with twenty-four waves currently available. This issue is important, since to counteract population ageing, many OECD countries encourage families to have more children. However, the literature comes to controversial conclusions as to the direction of the effect of the presence and number of children on marital stability. If children hinder marital stability, as some recent studies conclude, then we must exercise caution in implementing pro-natal family policies.

We focus on the time of conception rather than on actual births, to distinguish children conceived before or within marriage. According to the standard economic models, divorce occurs when the value of marriage falls short of the value of being single, for either or both parents. Children have their own preferences, which are usually unknown to the future parents, and if parents care for their children, this fact alone may bring considerable uncertainty into the household allocation of time and money (private expenditure). Children conceived before or after marriage may behave differently or 
may be valued differently by their parents, and especially so when one of the spouses is a step-parent, which may add to marital conflict.

Since relatively 'happier' couples may have more children than others, it is important to account for the potential endogeneity of fertility decisions in a model of marriage break-up and, in this context, we take an instrumental variable approach. We exploit information on the number of siblings of the respondent, the presence of multiple births, and the age at first intercourse to instrument the number of children conceived before and within first marriage. We find a significant and sizable deterrent effect of young children conceived within first marriage on the risk of divorce, while children conceived before the couple married have the opposite effect. These conclusions are robust to several specification checks. According to our main model estimates, each additional child conceived within first marriage reduces by 0.19 the probability of marital disruption. In contrast, children conceived before marriage are found to significantly increase the probability of parental divorce by about 0.1 .

These findings can be reconciled with those of other studies in the literature that find a non-significant or negative effect of children on marriage stability, as for example, in Scandinavian countries, where cohabitation is very common (Svarer and Verner 2008). Thus, perhaps Scandinavian couples more closely resemble US couples with children conceived before first marriage.

\section{References}

Alders, P. (2005) Human Capital Growth and Destruction: the Effect of Fertility on Skill Obsolescence, Economic Modelling, 22, 503-520.

Amato, P. (2004) The Consequences of Divorce for Adults and Children, Journal of Marriage and Family, 62, 1269-1287. 
Andersson, G. (1997) The Impact of Children on Divorce Risks of Swedish Women, European Journal of Population, 13, 109-145.

Angrist, J. and Evans, W. (1998) Children and Their Parents' Labor Supply: Evidence from Exogenous Variation in Family Size, American Economic Review, 88, 450-77.

Axinn, W., Clarkberg, M. and Thornton, A. (1994) Family Influences on Family Size Preferences, Demography, 31, 65-79.

Barnet-Verzat, C., Pailhé, A. and Solaz, A. (2011) Spending Time Together: The Impact of Children on Couples'Leisure Synchronization, Review of Economics of the Household, 9 , 465-486.

Baum, C., Schaffer, M., Stillman, S. (2007) Enhanced Routines for Instrumental Variables/GMM estimation and testing, Stata journal, 7, 465-506.

Beblo, M. (1999) Intrafamily Time Allocation: A Panel-Econometric Analysis in: Merz, J. and Ehling, M. (Hrsg.), Time Use-Research, Data and Policy, Baden-Baden, 473-489.

Becker, G., Landes, E. and Michael, R. (1977) An Economic Analysis of Marital Instability, The Journal of Political Economy, 85, 1141-1187.

Becker, G. (1981) A Treatise on the Family, Harvard University Press, Cambridge.

Bellido, H. and Marcén, M. (2014) Divorce Laws and Fertility, Labour Economics, 27, 56-70.

Bielecki, M. Goraus, K., Hagemejer, J. and Tyrowicz J. (2015) Decreasing Fertility vs Increasing Longevity: Raising the Retirement Age in the Context of Ageing Processes, Economic Modelling, In Press, Available online.

Black, S., Devereux, P. and Salvanes, K. (2005) Why the Apple Doesn't Fall Far: Understanding Intergenerational Transmission of Human Capital, The American Economic Review, 95, 437449.

Bloemen, H. and Stancanelli, E. (2015) Toyboys or Supergirls? An Analysis of Partners' Employment Outcomes When She Outearns Him, Review of the Economics of the Household, 13, 501-530.

Booth, A. and Kee, H. (2006) Intergenerational Transmission of Fertility Patterns in Britain, IZA DP $N^{\circ} 2437$. 
Burgess, S., Propper, C. and Aassve, A. (2003) The Role of Income in Marriage and Divorce Transitions among Young Americans, Journal of Population Economics, 16, 455-475.

Cáceres-Delpiano, J. and Giolito, E. (2008) How Unilateral Divorce Affects Children, IZA DP $N^{o} 3342$.

Cáceres-Delpiano, J. (2012) Impacts of Family Size on the Family as a Whole: Evidence from the Developing World, The B.E. Journal of Economic Analysis \& Policy, 12, 1-34.

Chan, T. and Halpin, B. (2002) Children and Marital Instability in the UK, Manuscript, Department of Sociology, University of Oxford.

Chandra, A., Martinez, G., Mosher, W., Abma, J. and Jones, J. (2005) Fertility, Family Planning, and Reproductive Health of U.S. Women: Data from the 2002 National Survey of Family Growth, National Center for Health Statistics, Vital Health Stat, 23. Downloaded from: http://www.cdc.gov/nchs/data/series/sr_23/sr23_025.pdf

Cherlin, A. (1977) The Effect of Children on Marital Dissolution, Demography, 14, 265-272.

Currie, J. and Moretti, E. (2003) Mother's Education and the Intergenerational Transmission of Human Capital: Evidence from College Openings, The Quarterly Journal of Economics, 118, $1495-1532$.

Dahl, G. and Moretti, E. (2008) The Demand for Sons, Review of Economic Studies, 75, 10851120.

Del Bono, E., Ermisch, J. and Francesconi, M. (2012) Intrafamily Resource Allocations: A Dynamic Structural Model of Birth Weight, Journal of Labor Economics, 30, 657-706.

Ermisch, J. (2008) Child Support and Non-Resident Fathers' Contact with Their Children, Journal of Population Economics, 21, 827-853.

Ermisch, J. and Pronzato, C. (2008) Intra-Household Allocation of Resources: Inferences from Non-Resident Fathers' Child Support Payments, Economic Journal, 118, 347-362.

Ermish, J. (2009) The Rising Share of Non-Marital Births: is it Only Compositional Effects?, Demography, 46, 193-202.

Fanti, L. and Spataro, L. (2013) On the Relationship between Fertility and Public National Debt, Economic Modelling, 33, 843-849. 
Friedberg, L. and Stern, S. (2003) The Economics of Marriage and Divorce, University of Virginia

Friedberg, L. (1998) Did Unilateral Divorce Raise Divorce Rates? Evidence from Panel Data, The American Economic Review, 88, 608-627.

Furtado, D., Marcen, M. and Sevilla A. (2013) Does Culture Affect Divorce? Evidence from European Immigrants in the United States, Demography, 50, 1013-1038.

Grossbard-Shechtman, S. (1993) On the Economics of Marriage - A Theory of Marriage, Labor and Divorce, Boulder, CO: Westview Press, 1993.

Grossbard-Shechtman, S. (2003) A Consumer Theory with Competitive Markets for Work in Marriage', Journal of Socio-Economics, 31, 609-645.

Jacobsen, J., Pearce III, J. and Rosenbloom, J. (2001) The Effects of Child-bearing on Women's Marital Status: Using Twin Births as a Natural Experiment, Economics Letters, 70, 133-138.

Johnson, W. and Skinner, J. (1986) Labor Supply and Marital Separation, The American Economic Review, 76, 455-469.

Koo, H. and Janowitz, B. (1983) Interrelationships between Fertility and Marital Dissolution: Results of a Simultaneous Logit Model, Demography, 20, 129-145.

Lau, S. (2014) Fertility and Mortality Changes in an Overlapping-Generations Model With Realistic Demography, Economic Modelling, 38, 512-521.

Lundberg, S. and Pollak, R. (2013) Cohabitation and the Uneven Retreat from Marriage in the U.S., 1950-2010, NBER Working Paper 1914.

Lundberg, S. and Rose, E. (2003) Child Gender and the Transition to Marriage, Demography, 40, 333-349.

Manning, W., Smock, P. and Majumdar, D. (2004) The Relative Stability of Cohabiting and Marital Unions for Children, Population Research and Policy Review, 23, 135-159.

Martínez, G., Chandra, A., Abma, J., Jones, J. and Mosher, W. (2006) Fertility, Contraception, and Fatherhood: Data on Men and Women from Cycle 6 (2002) of the National Survey of Family Growth, National Center for Health Statistics, Vital Health Stat, 23. Downloaded from: http://www.cdc.gov/nchs/data/series/sr_23/sr23_026.pdf 
Miller, B. and Heaton, T. (1991) Age at First Sexual Intercourse and the Timing of Marriage and Childbirth, Journal of Marriage and Family, 53, 719-732.

Myers, S. (1997) Marital Uncertainty and Childbearing, Social Forces, 75, 1271-1289.

Osborne, C., Manning, W. and Smock, P. (2007) Married and Cohabiting Parents' Relationship Stability: A Focus on Race and Ethnicity, Journal of Marriage and Family, 69, 1345-1366.

Rosenzweig, M. and Wolpin, K. (1980) Testing the Quantity-Quality Fertility Model: The Use of Twins as a Natural Experiment, Econometrica, 48, 227-40.

Rotz, D. (2011) Why Have Divorce Rates Fallen? The Role of Women's Age at Marriage, Harvard University, mimeo.

Sevilla-Sanz, A. (2010) Household Division of Labor and Cross-Country Differences in Household Formation Rates, Journal of Population Economics, 23, 225-249.

Smock, P. (1993) The Economic Costs of Marital Disruption for Young Women Over the Past Two Decades, Demography, 30, 353-371.

Smock, P. (1994) Gender and the Short-Run Economic Consequences of Marital Disruption, Social Forces, 73, 243-262.

Steele, F., Kallis, C., Goldstein, H. and Joshi, H. (2005) The Relationship between Childbearing and Transitions from Marriage and Cohabitation in Britain, Demography, 42, 647-673.

Stevenson, B. and Wolfers, J. (2006) Bargaining in the shadow of the law: Divorce laws and family distress, The Quarterly Journal of Economics, 121, 267-288.

Stevenson, B. and Wolfers, J. (2007) Marriage and Divorce: Changes and their Driving Forces, Journal of Economic Perspectives, 21, 27-52.

Svarer, M. and Verner, M. (2008) Do Children Stabilize Relationships in Denmark?, Journal of Population Economics, 21, 395-417.

Vaaler, M., Ellison, C. and Powers, D. (2009) Religious Influences on the Risk of Marital Dissolution, Journal of Marriage and Family, 71, 917-934.

Vuri, D. (2001) Fertility and Divorce, European University Institute, Working Paper ECO $2001 / 5$. 
Vuri, D. (2002) Propensity Score Estimates of the Effect of Fertility and Marital Dissolution, Working Paper ECO 2003/4.

Waite, L. and Lillard, L. (1993) A Joint Model of Marital Childbearing and Marital Disruption, Demography, 30, 653-681.

Wolfers, J. (2006) Did Unilateral Divorce Laws Raise Divorce Rates? A Reconciliation and New Results, American Economic Review, 96, 1802-1820. 
Figure 1 - USA Divorce Rates by Age

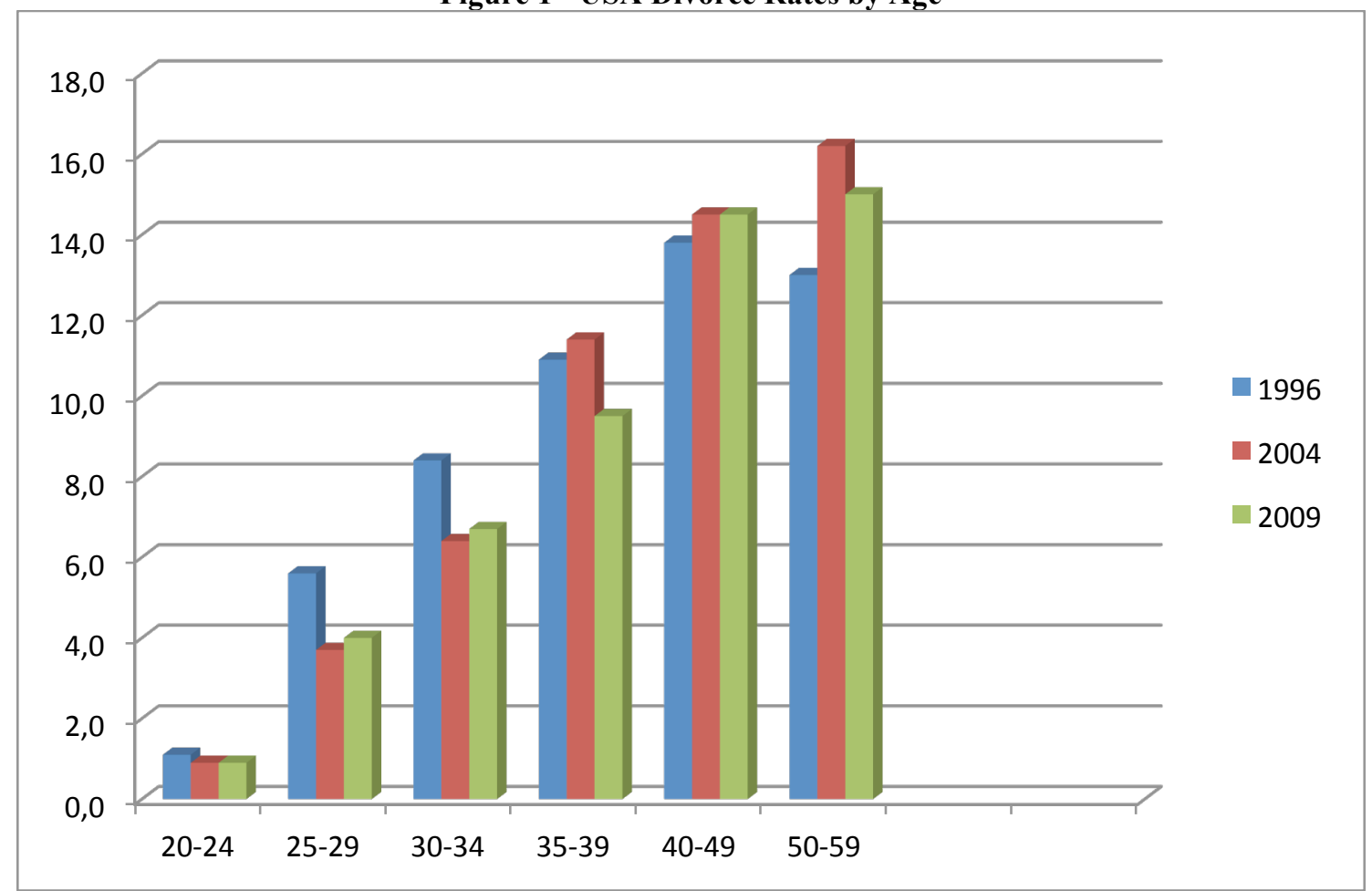

Note: Male divorce rates by age: white population, Survey of Income and Program Participation.

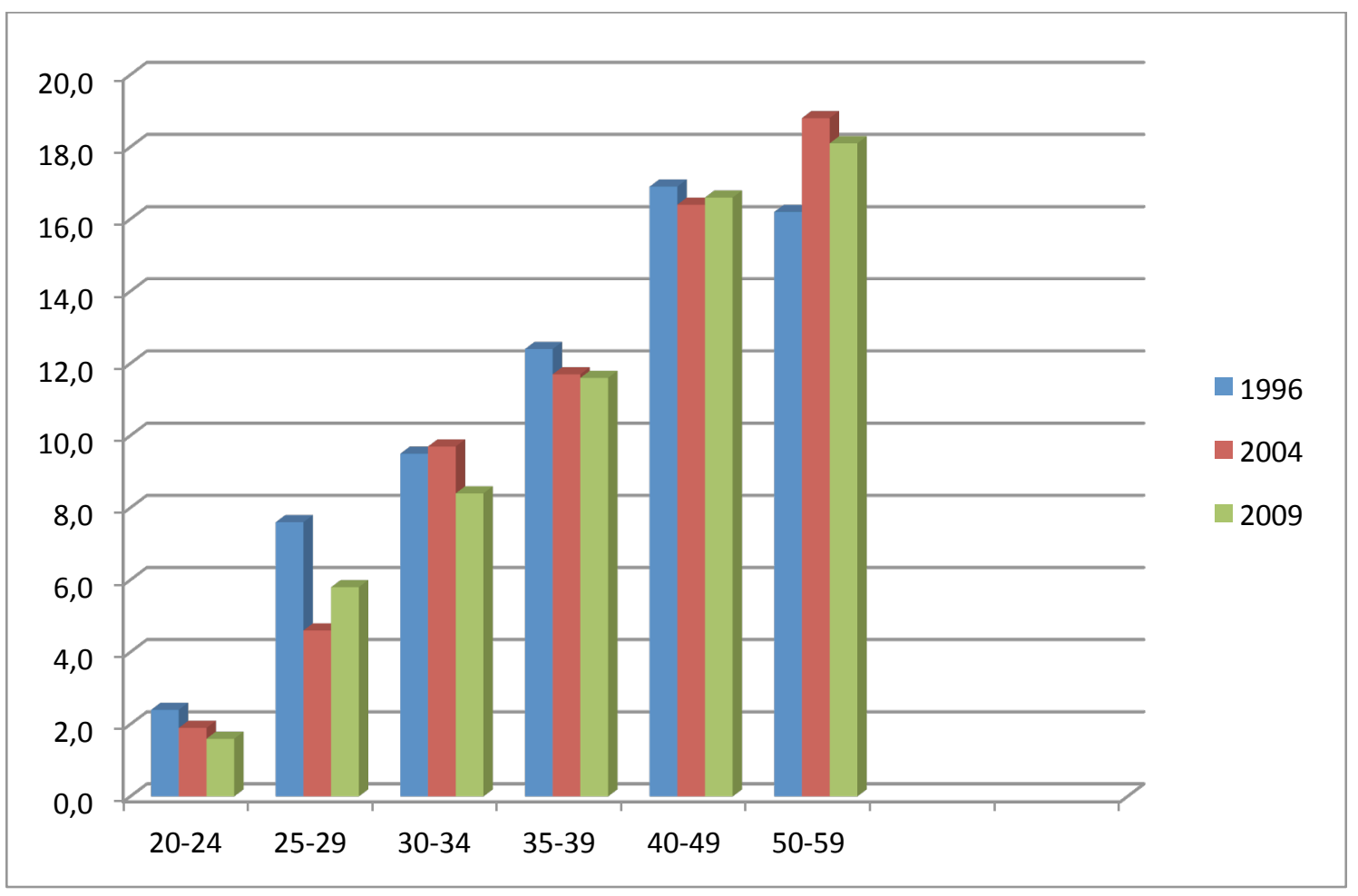

Note: Female divorce rates by age: white population, Survey of Income and Program Participation. 
Table 1 - Summary Statistics

\begin{tabular}{lcccc}
\hline \hline Variables & Mean & Std. Deviation & Minimum & Maximum \\
\hline Divorce & 0.046 & 0.209 & 0 & 1 \\
Children conceived within marriage & 1.090 & 1.085 & 0 & 10 \\
Children conceived before marriage & 0.356 & 0.725 & 0 & 9 \\
Man & 0.535 & 0.499 & 0 & 1 \\
Age & 33.160 & 7.038 & 21 & 51 \\
Age squared & 1149.108 & 497.092 & 441 & 2601 \\
Wife five years older & 0.033 & 0.180 & 0 & 1 \\
Husband five years older & 0.191 & 0.393 & 0 & 1 \\
Spouses of the Same age & 0.776 & 0.417 & 0 & 1 \\
Highest educ.: lowest level & 0.074 & 0.262 & 0 & 1 \\
Highest educ.: high school level & 0.369 & 0.483 & 0 & 1 \\
Highest educ.: college level & 0.247 & 0.431 & 0 & 1 \\
Highest educ.: more than college level & 0.310 & 0.462 & 0 & 1 \\
Highest educ. spouse: lowest level & 0.087 & 0.282 & 0 & 1 \\
Highest educ. spouse: high school level & 0.386 & 0.487 & 0 & 1 \\
Highest educ. spouse: college level & 0.237 & 0.425 & 0 & 1 \\
Highest educ. spouse: more than college level & 0.290 & 0.453 & 0 & 1 \\
Father in household in 1979 & 0.679 & 0.467 & 0 & 1 \\
Without father figure in 1979 & 0.010 & 0.102 & 0 & 1 \\
Father out household in 1979 & 0.310 & 0.463 & 0 & 1 \\
Charged illegal by 1980 & 0.073 & 0.260 & 0 & 1 \\
Age first marriage & 24.923 & 3.887 & 21 & 49 \\
Child before marriage & 0.154 & 0.360 & 0 & 1 \\
Race: Hispanic & 0.164 & 0.370 & 0 & 1 \\
Race: black & 0.191 & 0.393 & 0 & 1 \\
Race: other & 0.645 & 0.478 & 0 & 1 \\
Observations / Respondents & $45441 / 5574$ & & & \\
\hline Note: See Section 3 & & & & \\
\hline
\end{tabular}

Note: See Section 3 for more details.

Table 2 - Summary Statistics

\begin{tabular}{lcc}
\hline \hline \multicolumn{1}{c}{ Variables } & 'Divorcee' subsample & $\begin{array}{c}\text { 'Intact marriage' } \\
\text { subsample }\end{array}$ \\
\hline Observations / Respondents & $11186 / 2082$ & $34255 / 3492$ \\
Mean age at divorce & 31.79 & - \\
Mean age at first marriage & 24.47 & 25.07 \\
Mean number children conceived during first marriage & 0.77 & 1.19 \\
Mean number children conceived before first marriage & 0.51 & 0.31 \\
\% with lowest level of education & 10.66 & 6.38 \\
\% with high level of education & 44.69 & 34.40 \\
\% with college level of education & 26.12 & 24.21 \\
\% with more than college level of education & 18.53 & 35.02 \\
\% with spouse lowest level of education & 12.05 & 7.59 \\
\% with spouse high level of education & 46.68 & 36.02 \\
\% with spouse college level of education & 23.83 & 23.66 \\
\% with spouse more than college level of education & 17.43 & 32.74 \\
\% with father in household in 1979 & 61.73 & 69.92 \\
\% without father figure in 1979 & 1.38 & 0.95 \\
\% with father out household in 1979 & 36.89 & 29.14 \\
\% with child before marriage & 22.35 & 13.07 \\
\% race: black & 26.28 & 16.74 \\
\% race: other & 17.98 & 15.86 \\
\hline
\end{tabular}

Note: See Section 3 for more details. 
Table 3 - Results of estimation of the model.

(Sample of Respondents Over Age 21 at First Marriage)

(Dependent Variable: Risk of Marital Dissolution. Linear Probability Models)

\begin{tabular}{|c|c|c|c|c|c|}
\hline & $\begin{array}{l}\text { (1) IV Model } \\
\text { Divorce } \\
\text { Outcome }\end{array}$ & $\begin{array}{l}\text { First Stage } \\
\text { Children No. } \\
\text { Within } \\
\end{array}$ & $\begin{array}{c}\text { First Stage } \\
\text { Children No. } \\
\text { Before } \\
\end{array}$ & $\begin{array}{l}\text { (2) RE model } \\
\text { No instruments } \\
\text { for children }\end{array}$ & $\begin{array}{l}\text { (3) FE model } \\
\text { No instruments } \\
\text { for children }\end{array}$ \\
\hline Number children conceived within marriage & $\begin{array}{c}-0.192 * * * \\
(0.027)\end{array}$ & & & $\begin{array}{c}-0.015 * * * \\
(0.002)\end{array}$ & $\begin{array}{c}-0.015^{* * *} \\
(0.002)\end{array}$ \\
\hline Number children conceived before marriage & $\begin{array}{c}0.100^{* * *} \\
(0.019)\end{array}$ & & & $\begin{array}{c}0.020^{* * *} \\
(0.004)\end{array}$ & $\begin{array}{c}0.094^{* *} \\
(0.037)\end{array}$ \\
\hline Man & $\begin{array}{c}0.002 \\
(0.006)\end{array}$ & & & $\begin{array}{c}-0.014 * * \\
(0.006)\end{array}$ & \\
\hline Age & $\begin{array}{c}0.101 * * * \\
(0.012)\end{array}$ & & & $\begin{array}{c}0.030 * * * \\
(0.002)\end{array}$ & $\begin{array}{c}0.039 * * * \\
(0.002)\end{array}$ \\
\hline Age squared & $\begin{array}{c}-0.001 * * * \\
(0.000)\end{array}$ & & & $\begin{array}{c}-0.0003 * * * \\
(0.00002)\end{array}$ & $\begin{array}{c}-0.0005^{* * *} * \\
(0.00002)\end{array}$ \\
\hline Wife five years older & $\begin{array}{l}-0.010 \\
(0.015)\end{array}$ & & & $\begin{array}{c}0.039 * * * \\
(0.014)\end{array}$ & \\
\hline Husband five years older & $\begin{array}{l}0.012^{*} \\
(0.007)\end{array}$ & & & $\begin{array}{c}0.019 * * * \\
(0.007)\end{array}$ & \\
\hline Highest education: lowest level & $\begin{array}{l}0.010 \\
(0.015)\end{array}$ & & & $\begin{array}{c}0.044 * * * \\
(0.010)\end{array}$ & $\begin{array}{c}-0.039 * * \\
(0.018)\end{array}$ \\
\hline Highest education: high school level & $\begin{array}{c}0.014 \\
(0.009)\end{array}$ & & & $\begin{array}{c}0.036^{* * * *} \\
(0.007)\end{array}$ & $\begin{array}{l}-0.010 \\
(0.012)\end{array}$ \\
\hline Highest education: college level & $\begin{array}{l}0.014^{* *} * \\
(0.007)\end{array}$ & & & $\begin{array}{c}0.032 * * * \\
(0.006)\end{array}$ & $\begin{array}{l}0.019^{* *} \\
(0.009)\end{array}$ \\
\hline Highest education spouse: lowest level & $\begin{array}{l}-0.000 \\
(0.010)\end{array}$ & & & $\begin{array}{l}0.018^{* *} \\
(0.009)\end{array}$ & $\begin{array}{c}-0.028^{* *} \\
(0.012)\end{array}$ \\
\hline Highest education spouse: high school level & $\begin{array}{l}-0.011 \\
(0.007)\end{array}$ & & & $\begin{array}{l}0.010^{*} \\
(0.006)\end{array}$ & $\begin{array}{l}-0.013 \\
(0.009)\end{array}$ \\
\hline Highest education spouse: college level & $\begin{array}{l}-0.007 \\
(0.006)\end{array}$ & & & $\begin{array}{l}0.010^{*} \\
(0.006)\end{array}$ & $\begin{array}{l}-0.001 \\
(0.008)\end{array}$ \\
\hline Father in household in 1979 & $\begin{array}{l}-0.005 \\
(0.007)\end{array}$ & & & $\begin{array}{c}-0.027 * * * \\
(0.006)\end{array}$ & \\
\hline Without father figure in 1979 & $\begin{array}{l}-0.039 \\
(0.024)\end{array}$ & & & $\begin{array}{l}-0.007 \\
(0.026)\end{array}$ & \\
\hline Charged illegal by 1980 & $\begin{array}{c}0.020^{* *} \\
(0.010)\end{array}$ & & & $\begin{array}{c}0.046 * * * \\
(0.010)\end{array}$ & \\
\hline Age first marriage & $\begin{array}{c}-0.033 * * * \\
(0.004)\end{array}$ & & & $\begin{array}{c}-0.008^{* * *} \\
(0.001)\end{array}$ & \\
\hline Race: Hispanic & $\begin{array}{c}0.002 \\
(0.008)\end{array}$ & & & $\begin{array}{l}-0.005 \\
(0.008)\end{array}$ & \\
\hline Race: black & $\begin{array}{c}-0.029^{*} \\
(0.016)\end{array}$ & & & $\begin{array}{c}0.051^{* * *} \\
(0.008)\end{array}$ & \\
\hline Multiple birth & & $\begin{array}{c}0.568 * * * \\
(0.043)\end{array}$ & $\begin{array}{c}0.364 * * * \\
(0.021)\end{array}$ & & \\
\hline One sibling & & $\begin{array}{c}0.003 \\
(0.042)\end{array}$ & $\begin{array}{c}0.067 * * * \\
(0.021)\end{array}$ & & \\
\hline Two siblings & & $\begin{array}{c}0.049 \\
(0.041)\end{array}$ & $\begin{array}{c}0.096 * * * \\
(0.020)\end{array}$ & & \\
\hline Three siblings & & $\begin{array}{c}0.062 \\
(0.042)\end{array}$ & $\begin{array}{c}0.113 * * * \\
(0.021)\end{array}$ & & \\
\hline Four or more siblings & & $\begin{array}{c}0.112 * * * \\
(0.040)\end{array}$ & $\begin{array}{c}0.213 * * * \\
(0.020)\end{array}$ & & \\
\hline First intercourse before 16 & & $\begin{array}{c}-0.118 * * * \\
(0.028)\end{array}$ & $\begin{array}{c}0.430 * * * \\
(0.014)\end{array}$ & & \\
\hline First intercourse between 16 and 18 & & $\begin{array}{c}-0.117 * * * \\
(0.025)\end{array}$ & $\begin{array}{c}0.249 * * * \\
(0.012)\end{array}$ & & \\
\hline First intercourse after 18 & & $\begin{array}{c}-0.050^{*} \\
(0.028)\end{array}$ & $\begin{array}{c}0.117 * * * \\
(0.021)\end{array}$ & & \\
\hline Constant & $\begin{array}{c}-0.928 * * * \\
(0.119)\end{array}$ & $\begin{array}{c}-4.403 * * * \\
(0.092)\end{array}$ & $\begin{array}{c}-1.261 * * * \\
(0.046)\end{array}$ & $\begin{array}{c}-0.258 * * * \\
(0.032)\end{array}$ & $\begin{array}{c}-0.709^{* * *} \\
(0.034)\end{array}$ \\
\hline Children number instrumented & YES & & & NO & NO \\
\hline Individual Random effects & YES & YES & YES & YES & NO \\
\hline Individual Fixed Effects & NO & NO & NO & NO & YES \\
\hline Observations & 45441 & 45441 & 45441 & 45441 & 45441 \\
\hline Number of respondents & 5574 & 5574 & 5574 & 5574 & 5574 \\
\hline
\end{tabular}

Notes: For the first stage of regressions, only the estimates of the coefficients on the instruments are shown for the sake of concision. Specifications (2) and (3) assume that children are exogenous and thus we do not instrument them. All specifications include year and cohort dummies. *** Significant at the $1 \%$ level, ** Significant at the $5 \%$ level, * Significant at the $10 \%$ level. 
Table 4 - Results of estimation of the model for different education groups. (Sample of Respondents Over Age 21 at First Marriage)

(Dependent Variable: Risk of Marital Dissolution. Linear Probability Models)

\begin{tabular}{|c|c|c|c|}
\hline & $\begin{array}{c}\text { Lesser } \\
\text { Educated: } \\
\text { Divorce } \\
\text { Outcome }\end{array}$ & $\begin{array}{c}\text { Intermediate } \\
\text { Education : } \\
\text { Divorce } \\
\text { Outcome }\end{array}$ & $\begin{array}{c}\text { Highest } \\
\text { Educated: } \\
\text { Divorce } \\
\text { Outcome }\end{array}$ \\
\hline Number children conceived within marriage & $\begin{array}{c}-0.204 * * \\
(0.097)\end{array}$ & $\begin{array}{c}-0.158 * * * \\
(0.043)\end{array}$ & $\begin{array}{c}-0.166^{* * * *} \\
(0.030)\end{array}$ \\
\hline Number children conceived before marriage & $\begin{array}{l}-0.028 \\
(0.027)\end{array}$ & $\begin{array}{c}0.117 * * * \\
(0.032)\end{array}$ & $\begin{array}{c}0.092 * * * \\
(0.030)\end{array}$ \\
\hline Man & $\begin{array}{l}-0.031 \\
(0.029)\end{array}$ & $\begin{array}{c}0.010 \\
(0.010)\end{array}$ & $\begin{array}{l}-0.005 \\
(0.007)\end{array}$ \\
\hline Age & $\begin{array}{c}0.096 * * * \\
(0.034)\end{array}$ & $\begin{array}{c}0.087 * * * \\
(0.018)\end{array}$ & $\begin{array}{c}0.093 * * * \\
(0.014)\end{array}$ \\
\hline Age squared & $\begin{array}{c}-0.001 * * * \\
(0.000)\end{array}$ & $\begin{array}{c}-0.001 * * * \\
(0.000)\end{array}$ & $\begin{array}{c}-0.001 * * * \\
(0.000)\end{array}$ \\
\hline Wife five years older & $\begin{array}{l}-0.024 \\
(0.058)\end{array}$ & $\begin{array}{c}0.012 \\
(0.022)\end{array}$ & $\begin{array}{l}-0.024 \\
(0.020)\end{array}$ \\
\hline Husband five years older & $\begin{array}{c}0.049 * * \\
(0.024)\end{array}$ & $\begin{array}{l}-0.001 \\
(0.011)\end{array}$ & $\begin{array}{l}0.015^{*} \\
(0.009)\end{array}$ \\
\hline Father in household in 1979 & $\begin{array}{c}-0.057 * * * \\
(0.021)\end{array}$ & $\begin{array}{l}-0.015 \\
(0.011)\end{array}$ & $\begin{array}{l}0.006 \\
(0.009)\end{array}$ \\
\hline Without father figure in 1979 & $\begin{array}{l}-0.016 \\
(0.069)\end{array}$ & $\begin{array}{l}-0.061^{*} \\
(0.034)\end{array}$ & $\begin{array}{l}-0.012 \\
(0.040)\end{array}$ \\
\hline Charged illegal by 1980 & $\begin{array}{c}0.062 * * \\
(0.026)\end{array}$ & $\begin{array}{l}0.026^{*} \\
(0.014)\end{array}$ & $\begin{array}{c}0.002 \\
(0.016)\end{array}$ \\
\hline Age first marriage & $\begin{array}{c}-0.028^{* * * *} \\
(0.010)\end{array}$ & $\begin{array}{c}-0.030 * * * \\
(0.006)\end{array}$ & $\begin{array}{c}-0.027 * * * \\
(0.004)\end{array}$ \\
\hline Race: Hispanic & $\begin{array}{c}0.021 \\
(0.035)\end{array}$ & $\begin{array}{l}-0.002 \\
(0.014)\end{array}$ & $\begin{array}{l}0.005 \\
(0.011)\end{array}$ \\
\hline Race: black & $\begin{array}{l}0.081 * * \\
(0.032)\end{array}$ & $\begin{array}{c}-0.061^{*} \\
(0.032)\end{array}$ & $\begin{array}{l}-0.011 \\
(0.019)\end{array}$ \\
\hline Same education & $\begin{array}{c}0.018 \\
(0.028)\end{array}$ & $\begin{array}{c}-0.020 * * \\
(0.009)\end{array}$ & $\begin{array}{l}-0.006 \\
(0.007)\end{array}$ \\
\hline Respondent more educated than spouse & & $\begin{array}{l}-0.011 \\
(0.015)\end{array}$ & \\
\hline Constant & $\begin{array}{c}-0.831 * * \\
(0.371)\end{array}$ & $\begin{array}{c}-0.690^{* * *} \\
(0.178)\end{array}$ & $\begin{array}{c}-0.953 * * * \\
(0.163)\end{array}$ \\
\hline Individual Random effects & YES & YES & YES \\
\hline Observations & 3,376 & 16,782 & 25,283 \\
\hline Number of respondents & 570 & 2,374 & 2,919 \\
\hline
\end{tabular}

Notes: Same specification as in Table 3, IV Model Specification. The sample of estimation is split by education level, distinguishing the lesser-educated interviewees from interviewees with an intermediate level of education, and those with higher level of education. First stages of regressions are not shown for the sake of concision (available upon request). All columns include year and cohort dummies. *** Significant at the $1 \%$ level, $* *$ Significant at the $5 \%$ level, $*$ Significant at the $10 \%$ level. 
Table 5 - Results of estimation of the model for different gender groups.

(Sample of Respondents Over Age 21 at First Marriage)

(Dependent Variable: Risk of Marital Dissolution. Linear Probability Models)

\begin{tabular}{|c|c|c|}
\hline & $\begin{array}{c}\text { Men } \\
\text { Divorce } \\
\text { Outcome }\end{array}$ & $\begin{array}{c}\text { Women } \\
\text { Divorce } \\
\text { Outcome }\end{array}$ \\
\hline Number children conceived within marriage & $\begin{array}{c}-0.165^{* * *} \\
(0.035)\end{array}$ & $\begin{array}{c}-0.204 * * * \\
(0.039)\end{array}$ \\
\hline Number children conceived before marriage & $\begin{array}{c}0.075 * * \\
(0.030)\end{array}$ & $\begin{array}{c}0.113 * * * \\
(0.024)\end{array}$ \\
\hline Age & $\begin{array}{c}0.086^{* * * *} \\
(0.014)\end{array}$ & $\begin{array}{c}0.109^{* * *} \\
(0.018)\end{array}$ \\
\hline Age squared & $\begin{array}{c}-0.001 * * * \\
(0.000)\end{array}$ & $\begin{array}{c}-0.001^{* * * *} \\
(0.000)\end{array}$ \\
\hline Wife five years older & $\begin{array}{c}-0.033^{*} \\
(0.020)\end{array}$ & $\begin{array}{c}0.035 \\
(0.023)\end{array}$ \\
\hline Husband five years older & $\begin{array}{c}0.033 * * * \\
(0.008)\end{array}$ & $\begin{array}{l}-0.019 \\
(0.012)\end{array}$ \\
\hline Highest education: lowest level & $\begin{array}{c}0.014 \\
(0.017)\end{array}$ & $\begin{array}{c}0.001 \\
(0.026)\end{array}$ \\
\hline Highest education: high school level & $\begin{array}{c}0.017 \\
(0.012)\end{array}$ & $\begin{array}{c}0.011 \\
(0.013)\end{array}$ \\
\hline Highest education: college level & $\begin{array}{c}0.012 \\
(0.010)\end{array}$ & $\begin{array}{c}0.015 \\
(0.010)\end{array}$ \\
\hline Highest education spouse: lowest level & $\begin{array}{c}0.010 \\
(0.014)\end{array}$ & $\begin{array}{l}-0.016 \\
(0.015)\end{array}$ \\
\hline Highest education spouse: high school level & $\begin{array}{l}-0.009 \\
(0.010)\end{array}$ & $\begin{array}{c}-0.013 \\
(0.011)\end{array}$ \\
\hline Highest education spouse: college level & $\begin{array}{c}-0.007 \\
(0.008)\end{array}$ & $\begin{array}{c}0.001 \\
(0.010)\end{array}$ \\
\hline Father in household in 1979 & $\begin{array}{c}-0.015^{* *} \\
(0.007)\end{array}$ & $\begin{array}{c}0.004 \\
(0.011)\end{array}$ \\
\hline Without father figure in 1979 & $\begin{array}{c}-0.032 \\
(0.026)\end{array}$ & $\begin{array}{c}-0.068 \\
(0.044)\end{array}$ \\
\hline Charged illegal by 1980 & $\begin{array}{c}0.017 \\
(0.010)\end{array}$ & $\begin{array}{c}0.039 \\
(0.025)\end{array}$ \\
\hline Age first marriage & $\begin{array}{c}-0.028^{* * *} \\
(0.005)\end{array}$ & $\begin{array}{c}-0.036^{* * *} \\
(0.005)\end{array}$ \\
\hline Race: Hispanic & $\begin{array}{c}0.004 \\
(0.010)\end{array}$ & $\begin{array}{l}-0.003 \\
(0.013)\end{array}$ \\
\hline Race: black & $\begin{array}{l}-0.013 \\
(0.023)\end{array}$ & $\begin{array}{c}-0.038^{*} \\
(0.020)\end{array}$ \\
\hline Constant & $\begin{array}{c}-0.774 * * * \\
(0.134)\end{array}$ & $\begin{array}{c}-0.997 * * * \\
(0.194)\end{array}$ \\
\hline Individual Random effects & YES & YES \\
\hline Observations & 24,291 & 21,150 \\
\hline Number of respondents & 3,008 & 2,566 \\
\hline
\end{tabular}

Notes: Same specification as in Table 3, IV Model Specification. The sample of estimation is split by the gender of the respondent. First stages of regressions are not shown for the sake of concision (available upon request). All columns include year and cohort dummies. *** Significant at the $1 \%$ level, ** Significant at the $5 \%$ level, * Significant at the $10 \%$ level. 
Table 6 - Results of estimation of the model for different racial groups. (Sample of Respondents Over Age 21 at First Marriage)

(Dependent Variable: Risk of Marital Dissolution. Linear Probability Models)

\begin{tabular}{|c|c|c|c|}
\hline & $\begin{array}{c}\text { Black } \\
\text { Divorce } \\
\text { Outcome }\end{array}$ & $\begin{array}{l}\text { Divorce } \\
\text { Outcome }\end{array}$ & $\begin{array}{c}\text { White \& } \\
\text { other } \\
\text { Divorce } \\
\text { Outcome }\end{array}$ \\
\hline Number children conceived within marriage & $\begin{array}{c}-0.087 * * \\
(0.040)\end{array}$ & $\begin{array}{c}-0.116^{* *} \\
(0.047)\end{array}$ & $\begin{array}{c}-0.166 * * * \\
(0.030)\end{array}$ \\
\hline Number children conceived before marriage & $\begin{array}{l}-0.006 \\
(0.018)\end{array}$ & $\begin{array}{c}0.068 * * \\
(0.028)\end{array}$ & $\begin{array}{c}0.219 * * * \\
(0.043)\end{array}$ \\
\hline Man & $\begin{array}{l}-0.008 \\
(0.012)\end{array}$ & $\begin{array}{c}0.010 \\
(0.013)\end{array}$ & $\begin{array}{l}-0.001 \\
(0.007)\end{array}$ \\
\hline Age & $\begin{array}{c}0.047 * * * \\
(0.013)\end{array}$ & $\begin{array}{c}0.069^{* * * *} \\
(0.021)\end{array}$ & $\begin{array}{c}0.092 * * * \\
(0.014)\end{array}$ \\
\hline Age squared & $\begin{array}{c}-0.001 * * * \\
(0.000)\end{array}$ & $\begin{array}{c}-0.001 * * * \\
(0.000)\end{array}$ & $\begin{array}{c}-0.001 * * * \\
(0.000)\end{array}$ \\
\hline Wife five years older & $\begin{array}{c}0.006 \\
(0.027)\end{array}$ & $\begin{array}{c}-0.041 \\
(0.030)\end{array}$ & $\begin{array}{c}0.010 \\
(0.019)\end{array}$ \\
\hline Husband five years older & $\begin{array}{c}0.004 \\
(0.013)\end{array}$ & $\begin{array}{c}0.006 \\
(0.013)\end{array}$ & $\begin{array}{l}0.015^{*} \\
(0.008)\end{array}$ \\
\hline Highest education: lowest level & $\begin{array}{c}0.092 * * * \\
(0.027)\end{array}$ & $\begin{array}{l}-0.000 \\
(0.024)\end{array}$ & $\begin{array}{l}-0.037^{*} \\
(0.022)\end{array}$ \\
\hline Highest education: high school level & $\begin{array}{c}0.057 * * * \\
(0.020)\end{array}$ & $\begin{array}{c}0.015 \\
(0.016)\end{array}$ & $\begin{array}{c}0.004 \\
(0.011)\end{array}$ \\
\hline Highest education: college level & $\begin{array}{c}0.043 * * * \\
(0.015)\end{array}$ & $\begin{array}{l}0.015 \\
(0.015)\end{array}$ & $\begin{array}{c}0.008 \\
(0.008)\end{array}$ \\
\hline Highest education spouse: lowest level & $\begin{array}{c}0.015 \\
(0.022)\end{array}$ & $\begin{array}{l}0.008 \\
(0.019)\end{array}$ & $\begin{array}{l}-0.005 \\
(0.014)\end{array}$ \\
\hline Highest education spouse: high school level & $\begin{array}{c}0.009 \\
(0.015)\end{array}$ & $\begin{array}{c}0.016 \\
(0.016)\end{array}$ & $\begin{array}{c}-0.021^{* *} \\
(0.009)\end{array}$ \\
\hline Highest education spouse: college level & $\begin{array}{c}0.013 \\
(0.014)\end{array}$ & $\begin{array}{l}-0.003 \\
(0.014)\end{array}$ & $\begin{array}{l}-0.011 \\
(0.007)\end{array}$ \\
\hline Father in household in 1979 & $\begin{array}{c}-0.027 * * \\
(0.011)\end{array}$ & $\begin{array}{l}-0.005 \\
(0.013)\end{array}$ & $\begin{array}{c}0.008 \\
(0.009)\end{array}$ \\
\hline Without father figure in 1979 & $\begin{array}{l}-0.031 \\
(0.030)\end{array}$ & $\begin{array}{c}0.024 \\
(0.059)\end{array}$ & $\begin{array}{l}-0.009 \\
(0.039)\end{array}$ \\
\hline Charged illegal by 1980 & $\begin{array}{c}0.043^{* *} \\
(0.021)\end{array}$ & $\begin{array}{l}-0.033 \\
(0.024)\end{array}$ & $\begin{array}{c}0.020 \\
(0.013)\end{array}$ \\
\hline Age first marriage & $\begin{array}{c}-0.012 * * \\
(0.005)\end{array}$ & $\begin{array}{c}-0.024 * * * \\
(0.006)\end{array}$ & $\begin{array}{c}-0.029 * * * \\
(0.004)\end{array}$ \\
\hline Constant & $\begin{array}{c}-0.421 * * * \\
(0.134)\end{array}$ & $\begin{array}{c}-0.606^{* * * *} \\
(0.223)\end{array}$ & $\begin{array}{c}-0.898 * * * \\
(0.149)\end{array}$ \\
\hline Individual Random effects & YES & YES & YES \\
\hline Observations & 8,674 & 7,444 & 29,323 \\
\hline Number of respondents & 1,266 & 833 & 3,475 \\
\hline
\end{tabular}

Notes: Same specification as in Table 3, IV Model Specification. The sample of estimation is split by race, distinguishing Blacks, Hispanics, and White (the latter also including other races due to NLFS questionnaire design). First stages of regressions are not shown for the sake of concision (available upon request). All columns include year and cohort dummies. *** Significant at the $1 \%$ level, $* *$ Significant at the $5 \%$ level, * Significant at the $10 \%$ level. 
Table 7 - Results of estimation of the model split by sex of first child. (Sample of Respondents Over Age 21 at First Marriage)

(Dependent Variable: Risk of Marital Dissolution. Linear Probability Models)

\begin{tabular}{|c|c|c|c|}
\hline & $\begin{array}{l}\text { Divorce } \\
\text { Outcome }\end{array}$ & $\begin{array}{l}\text { Divorce } \\
\text { Outcome }\end{array}$ & $\begin{array}{l}\text { Divorce } \\
\text { Outcome }\end{array}$ \\
\hline Number children conceived within marriage & $\begin{array}{c}-0.185^{* * *} \\
(0.032)\end{array}$ & $\begin{array}{c}-0.194 * * * \\
(0.038)\end{array}$ & $\begin{array}{c}-0.151 * * * \\
(0.024)\end{array}$ \\
\hline Number children conceived before marriage & $\begin{array}{c}0.142 * * * \\
(0.028)\end{array}$ & $\begin{array}{c}0.115^{* * *} * \\
(0.029)\end{array}$ & $\begin{array}{c}0.057 * * * \\
(0.017)\end{array}$ \\
\hline First child conceived male & & & $\begin{array}{l}-0.001 \\
(0.005)\end{array}$ \\
\hline Man & $\begin{array}{c}0.005 \\
(0.007)\end{array}$ & $\begin{array}{l}-0.000 \\
(0.008)\end{array}$ & $\begin{array}{l}-0.001 \\
(0.005)\end{array}$ \\
\hline Age & $\begin{array}{c}0.091 * * * \\
(0.013)\end{array}$ & $\begin{array}{c}0.099 * * * \\
(0.016)\end{array}$ & $\begin{array}{c}0.085^{* * *} \\
(0.011)\end{array}$ \\
\hline Age squared & $\begin{array}{c}-0.001 * * * \\
(0.000)\end{array}$ & $\begin{array}{c}-0.001 * * * \\
(0.000)\end{array}$ & $\begin{array}{c}-0.001 * * * \\
(0.000)\end{array}$ \\
\hline Wife five years older & $\begin{array}{c}0.000 \\
(0.017)\end{array}$ & $\begin{array}{l}-0.026 \\
(0.022)\end{array}$ & $\begin{array}{c}0.008 \\
(0.015)\end{array}$ \\
\hline Husband five years older & $\begin{array}{c}0.007 \\
(0.008)\end{array}$ & $\begin{array}{c}0.009 \\
(0.010)\end{array}$ & $\begin{array}{c}0.019 * * * \\
(0.006)\end{array}$ \\
\hline Highest education: lowest level & $\begin{array}{l}-0.015 \\
(0.019)\end{array}$ & $\begin{array}{c}0.018 \\
(0.020)\end{array}$ & $\begin{array}{c}0.021 \\
(0.014)\end{array}$ \\
\hline Highest education: high school level & $\begin{array}{c}0.006 \\
(0.011)\end{array}$ & $\begin{array}{l}0.018 \\
(0.012)\end{array}$ & $\begin{array}{c}0.017 * * \\
(0.008)\end{array}$ \\
\hline Highest education: college level & $\begin{array}{c}0.017 * * \\
(0.009)\end{array}$ & $\begin{array}{c}0.015 \\
(0.009)\end{array}$ & $\begin{array}{c}0.013^{* *} \\
(0.007)\end{array}$ \\
\hline Highest education spouse: lowest level & $\begin{array}{l}-0.010 \\
(0.013)\end{array}$ & $\begin{array}{c}0.011 \\
(0.014)\end{array}$ & $\begin{array}{c}0.004 \\
(0.010)\end{array}$ \\
\hline Highest education spouse: high school level & $\begin{array}{l}-0.014 \\
(0.009)\end{array}$ & $\begin{array}{c}-0.013 \\
(0.010)\end{array}$ & $\begin{array}{l}-0.004 \\
(0.007)\end{array}$ \\
\hline Highest education spouse: college level & $\begin{array}{l}-0.009 \\
(0.008)\end{array}$ & $\begin{array}{l}-0.008 \\
(0.009)\end{array}$ & $\begin{array}{l}-0.001 \\
(0.006)\end{array}$ \\
\hline Father in household in 1979 & $\begin{array}{c}0.003 \\
(0.009)\end{array}$ & $\begin{array}{l}-0.007 \\
(0.009)\end{array}$ & $\begin{array}{c}-0.012^{* *} \\
(0.006)\end{array}$ \\
\hline Without father figure in 1979 & $\begin{array}{l}-0.014 \\
(0.031)\end{array}$ & $\begin{array}{c}-0.059^{*} \\
(0.034)\end{array}$ & $\begin{array}{l}-0.036 \\
(0.022)\end{array}$ \\
\hline Charged illegal by 1980 & $\begin{array}{c}0.020 \\
(0.012)\end{array}$ & $\begin{array}{c}0.032^{* *} \\
(0.014)\end{array}$ & $\begin{array}{c}0.015 \\
(0.009)\end{array}$ \\
\hline Age first marriage & $\begin{array}{c}-0.031 * * * \\
(0.004)\end{array}$ & $\begin{array}{c}-0.032 * * * \\
(0.005)\end{array}$ & $\begin{array}{c}-0.026^{* * * *} \\
(0.003)\end{array}$ \\
\hline Race: Hispanic & $\begin{array}{l}-0.004 \\
(0.010)\end{array}$ & $\begin{array}{l}-0.008 \\
(0.013)\end{array}$ & $\begin{array}{c}0.009 \\
(0.007)\end{array}$ \\
\hline Race: black & $\begin{array}{c}-0.055^{* * * *} \\
(0.021)\end{array}$ & $\begin{array}{l}-0.025 \\
(0.022)\end{array}$ & $\begin{array}{l}-0.006 \\
(0.014)\end{array}$ \\
\hline Constant & $\begin{array}{c}-0.822 * * * \\
(0.125)\end{array}$ & $\begin{array}{c}-0.890^{* * *} \\
(0.165)\end{array}$ & $\begin{array}{c}-0.792 * * * \\
(0.121)\end{array}$ \\
\hline Individual Random effects & YES & YES & YES \\
\hline Observations & 25,893 & 24,811 & 40,176 \\
\hline Number of respondents & 3,330 & 3,226 & 4,590 \\
\hline
\end{tabular}

Notes: Same specification as in Table 3, IV Model Specification. The sample of estimation is split by the sex of the first child, irrespective of being conceived before and during first marriage. Column (1) includes couples whose first child is a boy, and childless couples. Column (2) includes couples whose first child is a girl, and childless couples. Column (3) includes only couples who have children at some point, so not including childless couples. First stages of regressions are not shown for the sake of concision (available upon request). All columns include year and cohort dummies. *** Significant at the $1 \%$ level, ** Significant at the 5\% level, * Significant at the $10 \%$ level. 
Table 8 - Results of estimation of the model for different children age groups.

(Sample of Respondents Over Age 21 at First Marriage)

(Dependent Variable: Risk of Marital Dissolution. Linear Probability Models)

\begin{tabular}{|c|c|c|c|}
\hline & $\begin{array}{c}\text { Couples with } \\
\text { at least some } \\
\text { children aged } \\
0-2 \text { years } \\
\text { Divorce } \\
\text { Outcome }\end{array}$ & $\begin{array}{c}\text { Couples with } \\
\text { at least some } \\
\text { children aged } \\
\text { 3-9 years } \\
\text { Divorce } \\
\text { Outcome }\end{array}$ & $\begin{array}{l}\text { Couples with at } \\
\text { least some } \\
\text { children aged } \\
10 \text { or older } \\
\text { Divorce } \\
\text { Outcome }\end{array}$ \\
\hline Number children conceived within marriage $0-2$ & $\begin{array}{c}-0.435 * * * \\
(0.097)\end{array}$ & & \\
\hline Number children conceived before marriage 0 - 2 & $\begin{array}{c}0.440 * * * \\
(0.161)\end{array}$ & & \\
\hline Number children conceived within marriage 3 - 9 & & $\begin{array}{c}-0.320 * * * \\
(0.081)\end{array}$ & \\
\hline Number children conceived before marriage 3 - 9 & & $\begin{array}{c}0.189 * * * \\
(0.059)\end{array}$ & \\
\hline Number children conceived within marriage $>=10$ & & & $\begin{array}{c}-0.286^{* * * *} \\
(0.065)\end{array}$ \\
\hline Number children conceived before marriage $>=10$ & & & $\begin{array}{c}0.098^{* *} \\
(0.045)\end{array}$ \\
\hline Man & $\begin{array}{c}-0.026^{* * * *} \\
(0.009)\end{array}$ & $\begin{array}{l}-0.001 \\
(0.009)\end{array}$ & $\begin{array}{c}0.001 \\
(0.010)\end{array}$ \\
\hline Age & $\begin{array}{c}0.175 * * * \\
(0.036)\end{array}$ & $\begin{array}{c}0.140 * * * \\
(0.031)\end{array}$ & $\begin{array}{c}0.067 * * * \\
(0.011)\end{array}$ \\
\hline Age squared & $\begin{array}{c}-0.002 * * * \\
(0.000)\end{array}$ & $\begin{array}{c}-0.002 * * * \\
(0.000)\end{array}$ & $\begin{array}{c}-0.001 * * * \\
(0.000)\end{array}$ \\
\hline Wife five years older & $\begin{array}{l}-0.030 \\
(0.025)\end{array}$ & $\begin{array}{l}-0.011 \\
(0.027)\end{array}$ & $\begin{array}{c}-0.004 \\
(0.024)\end{array}$ \\
\hline Husband five years older & $\begin{array}{l}-0.010 \\
(0.012)\end{array}$ & $\begin{array}{l}-0.004 \\
(0.012)\end{array}$ & $\begin{array}{l}-0.007 \\
(0.011)\end{array}$ \\
\hline Highest education: lowest level & $\begin{array}{c}0.012 \\
(0.025)\end{array}$ & $\begin{array}{c}0.013 \\
(0.026)\end{array}$ & $\begin{array}{c}0.020 \\
(0.023)\end{array}$ \\
\hline Highest education: high school level & $\begin{array}{c}0.016 \\
(0.014)\end{array}$ & $\begin{array}{c}0.042 * * * \\
(0.014)\end{array}$ & $\begin{array}{c}0.017 \\
(0.014)\end{array}$ \\
\hline Highest education: college level & $\begin{array}{c}0.021^{* *} \\
(0.011)\end{array}$ & $\begin{array}{c}0.045^{* * * *} \\
(0.011)\end{array}$ & $\begin{array}{c}0.028 * * * \\
(0.010)\end{array}$ \\
\hline Highest education spouse: lowest level & $\begin{array}{c}0.023 \\
(0.019)\end{array}$ & $\begin{array}{l}-0.013 \\
(0.019)\end{array}$ & $\begin{array}{l}0.030^{*} \\
(0.017)\end{array}$ \\
\hline Highest education spouse: high school level & $\begin{array}{l}-0.009 \\
(0.012)\end{array}$ & $\begin{array}{l}-0.020 \\
(0.012)\end{array}$ & $\begin{array}{l}-0.009 \\
(0.011)\end{array}$ \\
\hline Highest education spouse: college level & $\begin{array}{l}-0.000 \\
(0.010)\end{array}$ & $\begin{array}{l}-0.003 \\
(0.010)\end{array}$ & $\begin{array}{l}-0.003 \\
(0.009)\end{array}$ \\
\hline Father in household in 1979 & $\begin{array}{l}-0.003 \\
(0.009)\end{array}$ & $\begin{array}{l}-0.000 \\
(0.011)\end{array}$ & $\begin{array}{l}-0.005 \\
(0.011)\end{array}$ \\
\hline Without father figure in 1979 & $\begin{array}{l}0.074^{*} \\
(0.044)\end{array}$ & $\begin{array}{l}-0.024 \\
(0.042)\end{array}$ & $\begin{array}{l}-0.070^{*} \\
(0.041)\end{array}$ \\
\hline Charged illegal by 1980 & $\begin{array}{c}0.016 \\
(0.016)\end{array}$ & $\begin{array}{l}0.003 \\
(0.017)\end{array}$ & $\begin{array}{c}0.034^{* *} \\
(0.016)\end{array}$ \\
\hline Age first marriage & $\begin{array}{c}-0.041 * * * \\
(0.008)\end{array}$ & $\begin{array}{c}-0.043 * * * \\
(0.009)\end{array}$ & $\begin{array}{c}-0.035^{* * * *} \\
(0.007)\end{array}$ \\
\hline Race: Hispanic & $\begin{array}{c}0.020 \\
(0.013)\end{array}$ & $\begin{array}{c}0.003 \\
(0.014)\end{array}$ & $\begin{array}{c}0.010 \\
(0.015)\end{array}$ \\
\hline Race: black & $\begin{array}{l}-0.009 \\
(0.020)\end{array}$ & $\begin{array}{c}-0.049^{*} \\
(0.030)\end{array}$ & $\begin{array}{l}-0.034 \\
(0.030)\end{array}$ \\
\hline Constant & $\begin{array}{c}-1.952 * * * \\
(0.421)\end{array}$ & $\begin{array}{c}-1.463 * * * \\
(0.354)\end{array}$ & $\begin{array}{c}-0.416^{* * * *} \\
(0.098)\end{array}$ \\
\hline $\begin{array}{l}\text { Observations } \\
\text { Number of respondents }\end{array}$ & $\begin{array}{c}20,044 \\
4,589\end{array}$ & $\begin{array}{c}20,216 \\
4689\end{array}$ & $\begin{array}{c}19,044 \\
4261\end{array}$ \\
\hline
\end{tabular}

Notes: Same specification as in Table 3, IV Model Specification. The sample of estimation in Column (1) includes childless couples, and couples with only children aged 0-2 conceived before or within marriage. In Column (2) we include childless couples, and couples with only children aged 3-9 conceived before or within marriage. In Column (3) we include childless couples, and couples with only children aged 10 or more conceived before or within marriage. First stages of regressions are not shown for the sake of concision (available upon request). All columns include year and cohort dummies. ${ }^{* * *}$ Significant at the $1 \%$ level, ${ }^{* *}$ Significant at the $5 \%$ level, $*$ Significant at the $10 \%$ level. 
Table 9 - Results of estimation of the model: Dropping Childless Couples from the Sample

(Sample of Respondents Over Age 21 at First Marriage)

(Dependent Variable: Risk of Marital Dissolution. Linear Probability Models)

\begin{tabular}{|c|c|c|c|}
\hline & $\begin{array}{l}\text { Divorce } \\
\text { Outcome }\end{array}$ & $\begin{array}{c}\text { First Stage } \\
\text { Children No. } \\
\text { Within }\end{array}$ & $\begin{array}{c}\text { First Stage } \\
\text { Children No. } \\
\text { Before }\end{array}$ \\
\hline Number children conceived within marriage & $\begin{array}{c}-0.062 * * * \\
(0.014)\end{array}$ & & \\
\hline Number children conceived before marriage & $\begin{array}{c}0.049 * * * \\
(0.015)\end{array}$ & & \\
\hline Man & $\begin{array}{c}0.001 \\
(0.003)\end{array}$ & & \\
\hline Age & $\begin{array}{c}0.042 * * * \\
(0.006)\end{array}$ & & \\
\hline Age squared & $\begin{array}{c}-0.0005^{* * *} * \\
(0.0001)\end{array}$ & & \\
\hline Wife five years older & $\begin{array}{l}0.0004 \\
(0.009)\end{array}$ & & \\
\hline Husband five years older & $\begin{array}{c}0.015 * * * \\
(0.004)\end{array}$ & & \\
\hline Highest education: lowest level & $\begin{array}{c}0.019 * * \\
(0.008)\end{array}$ & & \\
\hline Highest education: high school level & $\begin{array}{c}0.015 * * * \\
(0.005)\end{array}$ & & \\
\hline Highest education: college level & $\begin{array}{c}0.008 * * \\
(0.004)\end{array}$ & & \\
\hline Highest education spouse: lowest level & $\begin{array}{l}0.011^{*} \\
(0.006)\end{array}$ & & \\
\hline Highest education spouse: high school level & $\begin{array}{c}0.003 \\
(0.004)\end{array}$ & & \\
\hline Highest education spouse: college level & $\begin{array}{c}0.004 \\
(0.004)\end{array}$ & & \\
\hline Father in household in 1979 & $\begin{array}{c}-0.010^{* * * *} \\
(0.003)\end{array}$ & & \\
\hline Without father figure in 1979 & $\begin{array}{c}-0.024^{*} \\
(0.015)\end{array}$ & & \\
\hline Charged illegal by 1980 & $\begin{array}{c}0.004 \\
(0.006)\end{array}$ & & \\
\hline Age first marriage & $\begin{array}{c}-0.010 * * * \\
(0.002)\end{array}$ & & \\
\hline Race: Hispanic & $\begin{array}{c}0.002 \\
(0.004)\end{array}$ & & \\
\hline Race: black & $\begin{array}{c}0.001 \\
(0.008)\end{array}$ & & \\
\hline Multiple birth & & $\begin{array}{c}0.452 * * * \\
(0.029)\end{array}$ & $\begin{array}{c}0.106 * * * \\
(0.016)\end{array}$ \\
\hline One sibling & & $\begin{array}{l}-0.019 \\
(0.034)\end{array}$ & $\begin{array}{c}0.067 * * * \\
(0.019)\end{array}$ \\
\hline Two siblings & & $\begin{array}{c}0.047 \\
(0.033)\end{array}$ & $\begin{array}{c}0.078 * * * \\
(0.018)\end{array}$ \\
\hline Three siblings & & $\begin{array}{l}0.056^{*} \\
(0.033)\end{array}$ & $\begin{array}{c}0.101 * * * \\
(0.018)\end{array}$ \\
\hline Four or more siblings & & $\begin{array}{c}0.097 * * * \\
(0.032)\end{array}$ & $\begin{array}{c}0.162^{* * *} \\
(0.018)\end{array}$ \\
\hline First intercourse before 16 & & $\begin{array}{c}-0.093 * * * \\
(0.022)\end{array}$ & $\begin{array}{c}0.287 * * * \\
(0.012)\end{array}$ \\
\hline First intercourse between 16 and 18 & & $\begin{array}{c}-0.096 * * * \\
(0.019)\end{array}$ & $\begin{array}{c}0.128^{* * *} \\
(0.011)\end{array}$ \\
\hline First intercourse after 18 & & $\begin{array}{l}-0.019 \\
(0.020)\end{array}$ & $\begin{array}{c}0.051 * * * \\
(0.011)\end{array}$ \\
\hline Constant & $\begin{array}{c}-0.466 * * * \\
(0.074)\end{array}$ & $\begin{array}{c}-5.049 * * * \\
(0.100)\end{array}$ & $\begin{array}{c}-0.651 * * * \\
(0.056)\end{array}$ \\
\hline Individual Random effects & YES & & \\
\hline Observations & 35,453 & 35,453 & 35,453 \\
\hline Number of respondents & 3,408 & 3,408 & 3,408 \\
\hline
\end{tabular}

Notes: Same specification as in Table 3, IV Model Specification. For the first stage of regressions only the estimates of the coefficients on the instruments are shown for the sake of concision. All columns include year and cohort dummies. *** Significant at the $1 \%$ level, ** Significant at the $5 \%$ level, * Significant at the $10 \%$ level. 
Table 10 - Results of estimation of the model: Including Additional Covariates

(Sample of Respondents Over Age 21 at First Marriage)

(Dependent Variable: Risk of Marital Dissolution. Linear Probability Models)

\begin{tabular}{|c|c|c|c|c|c|c|}
\hline & $\begin{array}{c}\text { IV model } \\
(1) \\
\text { Divorce } \\
\text { outcome }\end{array}$ & $\begin{array}{c}\text { IV model } \\
(2) \\
\text { Divorce } \\
\text { outcome }\end{array}$ & $\begin{array}{c}\text { IV model } \\
(3) \\
\text { Divorce } \\
\text { outcome }\end{array}$ & $\begin{array}{c}\text { IV model } \\
(4) \\
\text { Divorce } \\
\text { outcome }\end{array}$ & $\begin{array}{c}\text { IV model } \\
(5) \\
\text { Divorce } \\
\text { outcome }\end{array}$ & $\begin{array}{c}\text { IV model } \\
(6) \\
\text { Divorce } \\
\text { outcome }\end{array}$ \\
\hline Number children within marriage & $\begin{array}{c}-0.192 * * * \\
(0.027)\end{array}$ & $\begin{array}{c}-0.202 * * * \\
(0.030)\end{array}$ & $\begin{array}{c}-0.196^{* * *} \\
(0.027)\end{array}$ & $\begin{array}{c}-0.185^{* * *} \\
(0.026)\end{array}$ & $\begin{array}{c}-0.268 * * * \\
(0.045)\end{array}$ & $\begin{array}{c}-0.271 * * * \\
(0.047)\end{array}$ \\
\hline Number children before marriage & $\begin{array}{c}0.100 * * * \\
(0.019)\end{array}$ & $\begin{array}{c}0.097 * * * \\
(0.022)\end{array}$ & $\begin{array}{c}0.101 * * * \\
(0.019)\end{array}$ & $\begin{array}{c}0.105 * * * \\
(0.020)\end{array}$ & $\begin{array}{c}0.108 * * * \\
(0.029)\end{array}$ & $\begin{array}{c}0.110 * * * \\
(0.028)\end{array}$ \\
\hline Man & $\begin{array}{c}0.002 \\
(0.006)\end{array}$ & $\begin{array}{c}0.004 \\
(0.006)\end{array}$ & $\begin{array}{c}0.002 \\
(0.006)\end{array}$ & $\begin{array}{c}0.003 \\
(0.006)\end{array}$ & $\begin{array}{c}0.002 \\
(0.008)\end{array}$ & $\begin{array}{c}0.006 \\
(0.008)\end{array}$ \\
\hline Age & $\begin{array}{c}0.101 * * * \\
(0.012)\end{array}$ & $\begin{array}{c}0.106^{* * *} * \\
(0.013)\end{array}$ & $\begin{array}{c}0.103 * * * \\
(0.012)\end{array}$ & $\begin{array}{c}0.098 * * * \\
(0.012)\end{array}$ & $\begin{array}{c}0.154 * * * \\
(0.022)\end{array}$ & $\begin{array}{c}0.157 * * * \\
(0.023)\end{array}$ \\
\hline Age squared & $\begin{array}{c}-0.001 * * * \\
(0.000)\end{array}$ & $\begin{array}{c}-0.001 * * * \\
(0.000)\end{array}$ & $\begin{array}{c}-0.001 * * * \\
(0.000)\end{array}$ & $\begin{array}{c}-0.001 * * * \\
(0.000)\end{array}$ & $\begin{array}{c}-0.002 * * * \\
(0.000)\end{array}$ & $\begin{array}{c}-0.002 * * * \\
(0.000)\end{array}$ \\
\hline Wife five years older & $\begin{array}{l}-0.010 \\
(0.015)\end{array}$ & $\begin{array}{c}-0.029^{*} \\
(0.018)\end{array}$ & $\begin{array}{l}-0.013 \\
(0.016)\end{array}$ & $\begin{array}{c}-0.008 \\
(0.016)\end{array}$ & $\begin{array}{c}0.014 \\
(0.021)\end{array}$ & $\begin{array}{c}0.004 \\
(0.022)\end{array}$ \\
\hline Husband five years older & $\begin{array}{l}0.012^{*} \\
(0.007)\end{array}$ & $\begin{array}{c}0.015 * * \\
(0.007)\end{array}$ & $\begin{array}{l}0.013^{*} \\
(0.007)\end{array}$ & $\begin{array}{c}0.011 \\
(0.007)\end{array}$ & $\begin{array}{c}0.014 \\
(0.009)\end{array}$ & $\begin{array}{c}0.013 \\
(0.009)\end{array}$ \\
\hline Highest education: lowest level & $\begin{array}{c}0.010 \\
(0.015)\end{array}$ & $\begin{array}{c}0.001 \\
(0.016)\end{array}$ & $\begin{array}{c}0.010 \\
(0.015)\end{array}$ & $\begin{array}{c}0.008 \\
(0.015)\end{array}$ & $\begin{array}{c}0.010 \\
(0.021)\end{array}$ & $\begin{array}{c}0.002 \\
(0.021)\end{array}$ \\
\hline Highest education: high school level & $\begin{array}{c}0.014 \\
(0.009)\end{array}$ & $\begin{array}{c}0.006 \\
(0.009)\end{array}$ & $\begin{array}{c}0.014 \\
(0.009)\end{array}$ & $\begin{array}{c}0.009 \\
(0.009)\end{array}$ & $\begin{array}{c}0.015 \\
(0.012)\end{array}$ & $\begin{array}{c}0.004 \\
(0.013)\end{array}$ \\
\hline Highest education: college level & $\begin{array}{c}0.014 * * \\
(0.007)\end{array}$ & $\begin{array}{c}0.006 \\
(0.007)\end{array}$ & $\begin{array}{c}0.014 * * \\
(0.007)\end{array}$ & $\begin{array}{c}0.011 \\
(0.007)\end{array}$ & $\begin{array}{l}0.018^{*} \\
(0.010)\end{array}$ & $\begin{array}{c}0.013 \\
(0.010)\end{array}$ \\
\hline Highest education spouse: lowest level & $\begin{array}{l}-0.000 \\
(0.010)\end{array}$ & $\begin{array}{c}-0.002 \\
(0.011)\end{array}$ & $\begin{array}{l}-0.001 \\
(0.010)\end{array}$ & $\begin{array}{c}-0.002 \\
(0.010)\end{array}$ & $\begin{array}{l}-0.000 \\
(0.014)\end{array}$ & $\begin{array}{c}-0.009 \\
(0.014)\end{array}$ \\
\hline Highest education spouse: high school level & $\begin{array}{l}-0.011 \\
(0.007)\end{array}$ & $\begin{array}{c}-0.015^{*} \\
(0.008)\end{array}$ & $\begin{array}{c}-0.011 \\
(0.007)\end{array}$ & $\begin{array}{l}-0.010 \\
(0.007)\end{array}$ & $\begin{array}{l}-0.008 \\
(0.010)\end{array}$ & $\begin{array}{c}-0.011 \\
(0.010)\end{array}$ \\
\hline Highest education spouse: college level & $\begin{array}{l}-0.007 \\
(0.006)\end{array}$ & $\begin{array}{c}-0.014 * \\
(0.007)\end{array}$ & $\begin{array}{l}-0.007 \\
(0.006)\end{array}$ & $\begin{array}{l}-0.006 \\
(0.006)\end{array}$ & $\begin{array}{c}0.001 \\
(0.009)\end{array}$ & $\begin{array}{l}-0.001 \\
(0.009)\end{array}$ \\
\hline Father in household in 1979 & $\begin{array}{l}-0.005 \\
(0.007)\end{array}$ & $\begin{array}{l}-0.001 \\
(0.008)\end{array}$ & $\begin{array}{l}-0.006 \\
(0.007)\end{array}$ & $\begin{array}{c}-0.002 \\
(0.007)\end{array}$ & $\begin{array}{l}-0.007 \\
(0.009)\end{array}$ & $\begin{array}{c}-0.002 \\
(0.009)\end{array}$ \\
\hline Without father figure in 1979 & $\begin{array}{c}-0.039 \\
(0.024)\end{array}$ & $\begin{array}{c}-0.050^{*} \\
(0.027)\end{array}$ & $\begin{array}{l}-0.039 \\
(0.024)\end{array}$ & $\begin{array}{l}-0.036 \\
(0.026)\end{array}$ & $\begin{array}{l}-0.056 \\
(0.034)\end{array}$ & $\begin{array}{l}-0.053 \\
(0.037)\end{array}$ \\
\hline Charged illegal by 1980 & $\begin{array}{c}0.020 * * \\
(0.010)\end{array}$ & $\begin{array}{l}0.022 * \\
(0.011)\end{array}$ & $\begin{array}{c}0.021 * * \\
(0.010)\end{array}$ & $\begin{array}{l}0.020^{*} \\
(0.010)\end{array}$ & $\begin{array}{c}0.010 \\
(0.014)\end{array}$ & $\begin{array}{c}0.011 \\
(0.015)\end{array}$ \\
\hline Age first marriage & $\begin{array}{c}-0.033 * * * \\
(0.004)\end{array}$ & $\begin{array}{c}-0.034 * * * \\
(0.004)\end{array}$ & $\begin{array}{c}-0.033 * * * \\
(0.004)\end{array}$ & $\begin{array}{c}-0.031 * * * \\
(0.004)\end{array}$ & $\begin{array}{c}-0.054 * * * \\
(0.008)\end{array}$ & $\begin{array}{c}-0.053 * * * \\
(0.008)\end{array}$ \\
\hline Race: Hispanic & $\begin{array}{c}0.002 \\
(0.008)\end{array}$ & $\begin{array}{c}0.002 \\
(0.009)\end{array}$ & $\begin{array}{c}0.002 \\
(0.009)\end{array}$ & $\begin{array}{c}0.004 \\
(0.009)\end{array}$ & $\begin{array}{c}0.007 \\
(0.012)\end{array}$ & $\begin{array}{c}0.005 \\
(0.012)\end{array}$ \\
\hline Race: black & $\begin{array}{c}-0.029^{*} \\
(0.016)\end{array}$ & $\begin{array}{c}-0.040 * * \\
(0.017)\end{array}$ & $\begin{array}{c}-0.028^{*} \\
(0.016)\end{array}$ & $\begin{array}{c}-0.031^{*} \\
(0.016)\end{array}$ & $\begin{array}{l}-0.030 \\
(0.022)\end{array}$ & $\begin{array}{c}-0.032 \\
(0.022)\end{array}$ \\
\hline Family income indicator & & $\begin{array}{c}-0.070 * * * \\
(0.013)\end{array}$ & & & & $\begin{array}{c}-0.070 * * * \\
(0.015)\end{array}$ \\
\hline Family income indicator squared & & $\begin{array}{c}0.011^{* * *} * \\
(0.002)\end{array}$ & & & & $\begin{array}{c}0.011 * * * \\
(0.002)\end{array}$ \\
\hline Religion raised: protestant & & & $\begin{array}{c}0.011 \\
(0.015)\end{array}$ & & & $\begin{array}{c}0.000 \\
(0.021)\end{array}$ \\
\hline Religion raised: roman catholic & & & $\begin{array}{c}0.015 \\
(0.016)\end{array}$ & & & $\begin{array}{c}0.010 \\
(0.022)\end{array}$ \\
\hline Religion raised: jewish & & & $\begin{array}{c}0.037 \\
(0.029)\end{array}$ & & & $\begin{array}{c}0.018 \\
(0.039)\end{array}$ \\
\hline Religion raised: other religion & & & $\begin{array}{c}0.016 \\
(0.017)\end{array}$ & & & $\begin{array}{c}0.013 \\
(0.023)\end{array}$ \\
\hline Living urban & & & & $\begin{array}{l}-0.001 \\
(0.004)\end{array}$ & & $\begin{array}{c}0.003 \\
(0.006)\end{array}$ \\
\hline Employed & & & & & $\begin{array}{c}-0.046 * * * \\
(0.010)\end{array}$ & $\begin{array}{c}-0.046 * * * \\
(0.010)\end{array}$ \\
\hline Spouse employed & & & & & $\begin{array}{c}-0.057 * * * \\
(0.011)\end{array}$ & $\begin{array}{c}-0.056^{* * *} \\
(0.012)\end{array}$ \\
\hline Constant & $\begin{array}{c}-0.928 * * * \\
(0.119)\end{array}$ & $\begin{array}{c}-0.960 * * * \\
(0.135)\end{array}$ & $\begin{array}{c}-0.959 * * * \\
(0.127)\end{array}$ & $\begin{array}{c}-0.906^{* * *} \\
(0.120)\end{array}$ & $\begin{array}{c}-1.262 * * * \\
(0.195)\end{array}$ & $\begin{array}{c}-1.324 * * * \\
(0.219)\end{array}$ \\
\hline Individual Random effects & YES & YES & YES & YES & YES & YES \\
\hline Observations & 45441 & 39,625 & 45,344 & 43,305 & 31,161 & 29,799 \\
\hline Number of respondents & 5574 & 5,351 & 5,556 & 5,359 & 5,148 & 4,911 \\
\hline
\end{tabular}

Notes: Same specification as in Table 3, IV Model Specification, which is reported in the first set of results here again, for comparison purposes. Specifications (2), (3), (4) and (5) include additionally among the covariates, respectively, controls for the family income and its square (2), the religion under which the interviewees were raised (3), whether the interviewee's current residence is urban or rural (4), and whether the interviewee and his/her spouse are employed (5). Specification (6) includes all these additional controls simultaneously. First stages of regressions are not shown for the sake of concision (available upon request). All columns include year and cohort dummies. *** Significant at the $1 \%$ level, ** Significant at the $5 \%$ level, * Significant at the $10 \%$ level. 
Table 11 - Results of estimation of the model. Robustness checks: dropping siblings from the instruments.

(Sample of Respondents Over Age 21 at First Marriage)

(Dependent Variable: Risk of Marital Dissolution. Linear Probability Models)

\begin{tabular}{|c|c|c|c|}
\hline & $\begin{array}{c}\text { IV model (4) } \\
\text { Divorce } \\
\text { outcome } \\
\end{array}$ & $\begin{array}{c}\text { First Stage } \\
\text { Children No. } \\
\text { Within }\end{array}$ & $\begin{array}{c}\text { First Stage } \\
\text { Children No. } \\
\text { Before }\end{array}$ \\
\hline Number children conceived within marriage & $\begin{array}{c}-0.158 * * * \\
(0.025)\end{array}$ & & \\
\hline Number children conceived before marriage & $\begin{array}{c}0.121 * * * \\
(0.019)\end{array}$ & & \\
\hline Man & $\begin{array}{c}0.004 \\
(0.005)\end{array}$ & & \\
\hline Age & $\begin{array}{c}0.085 * * * \\
(0.011)\end{array}$ & & \\
\hline Age squared & $\begin{array}{c}-0.001 * * * \\
(0.000)\end{array}$ & & \\
\hline Wife five years older & $\begin{array}{c}0.001 \\
(0.014)\end{array}$ & & \\
\hline Husband five years older & $\begin{array}{c}0.013 * * \\
(0.006)\end{array}$ & & \\
\hline Highest education: lowest level & $\begin{array}{l}-0.007 \\
(0.014)\end{array}$ & & \\
\hline Highest education: high school level & $\begin{array}{c}0.005 \\
(0.008)\end{array}$ & & \\
\hline Highest education: college level & $\begin{array}{c}0.010 \\
(0.006)\end{array}$ & & \\
\hline Highest education spouse: lowest level & $\begin{array}{l}-0.006 \\
(0.010)\end{array}$ & & \\
\hline Highest education spouse: high school level & $\begin{array}{l}-0.012 * \\
(0.007)\end{array}$ & & \\
\hline Highest education spouse: college level & $\begin{array}{l}-0.006 \\
(0.006)\end{array}$ & & \\
\hline Father in household in 1979 & $\begin{array}{l}-0.003 \\
(0.006)\end{array}$ & & \\
\hline Without father figure in 1979 & $\begin{array}{l}-0.041^{*} \\
(0.022)\end{array}$ & & \\
\hline Charged illegal by 1980 & $\begin{array}{l}0.018 * \\
(0.009)\end{array}$ & & \\
\hline Age first marriage & $\begin{array}{c}-0.029 * * * \\
(0.003)\end{array}$ & & \\
\hline Race: Hispanic & $\begin{array}{c}-0.004 \\
(0.008)\end{array}$ & & \\
\hline Race: black & $\begin{array}{c}-0.042 * * * \\
(0.015)\end{array}$ & & \\
\hline Multiple birth & & $\begin{array}{c}0.577 * * * \\
(0.041)\end{array}$ & $\begin{array}{c}0.365 * * * \\
(0.021)\end{array}$ \\
\hline First intercourse before 16 & & $\begin{array}{c}-0.115 * * * \\
(0.027)\end{array}$ & $\begin{array}{c}0.425 * * * \\
(0.014)\end{array}$ \\
\hline First intercourse between 16 and 18 & & $\begin{array}{c}-0.117 * * * \\
(0.024)\end{array}$ & $\begin{array}{c}0.244 * * * \\
(0.012)\end{array}$ \\
\hline First intercourse after 18 & & $\begin{array}{c}-0.049 * \\
(0.026)\end{array}$ & $\begin{array}{c}0.116^{* * *} \\
(0.014)\end{array}$ \\
\hline Constant & $\begin{array}{c}-0.737 * * * \\
(0.114)\end{array}$ & $\begin{array}{c}-4.313 * * * \\
(0.083)\end{array}$ & $\begin{array}{c}-1.156^{* * *} \\
(0.043)\end{array}$ \\
\hline Individual Random effects & YES & & \\
\hline Observations & 45441 & 45441 & 45441 \\
\hline Number of respondents & 5574 & 5574 & 5574 \\
\hline
\end{tabular}

Notes: For the first stage of regressions only the estimates of the coefficients on the instruments are shown for the sake of concision. All specifications include year and cohort dummies. $* * *$ Significant at the $1 \%$ level, $* *$ Significant at the $5 \%$ level, $*$ Significant at the $10 \%$ level. 
Table 12 - Results of estimation of the model. Robustness checks: dropping multiple births from the instruments. (Sample of Respondents Over Age 21 at First Marriage)

(Dependent Variable: Risk of Marital Dissolution. Linear Probability Models)

\begin{tabular}{|c|c|c|c|}
\hline & $\begin{array}{l}\text { IV model } \\
\text { (5) Divorce } \\
\text { outcome }\end{array}$ & $\begin{array}{l}\text { First Stage } \\
\text { Children No. } \\
\text { Within }\end{array}$ & $\begin{array}{c}\text { First Stage } \\
\text { Children No. } \\
\text { Before }\end{array}$ \\
\hline Number children conceived within marriage & $\begin{array}{c}-0.336^{* * *} \\
(0.080)\end{array}$ & & \\
\hline Number children conceived before marriage & $\begin{array}{c}0.080 * * * \\
(0.030)\end{array}$ & & \\
\hline Man & $\begin{array}{c}0.001 \\
(0.009)\end{array}$ & & \\
\hline Age & $\begin{array}{c}0.170 * * * \\
(0.035)\end{array}$ & & \\
\hline Age squared & $\begin{array}{c}-0.002 * * * \\
(0.000)\end{array}$ & & \\
\hline Wife five years older & $\begin{array}{l}-0.050 \\
(0.032)\end{array}$ & & \\
\hline Husband five years older & $\begin{array}{c}0.010 \\
(0.010)\end{array}$ & & \\
\hline Highest education: lowest level & $\begin{array}{c}0.054^{* *} \\
(0.025)\end{array}$ & & \\
\hline Highest education: high school level & $\begin{array}{c}0.033^{* *} \\
(0.013)\end{array}$ & & \\
\hline Highest education: college level & $\begin{array}{l}0.017^{*} \\
(0.009)\end{array}$ & & \\
\hline Highest education spouse: lowest level & $\begin{array}{c}0.006 \\
(0.014)\end{array}$ & & \\
\hline Highest education spouse: high school level & $\begin{array}{l}-0.015 \\
(0.010)\end{array}$ & & \\
\hline Highest education spouse: college level & $\begin{array}{l}-0.012 \\
(0.009)\end{array}$ & & \\
\hline Father in household in 1979 & $\begin{array}{l}-0.005 \\
(0.011)\end{array}$ & & \\
\hline Without father figure in 1979 & $\begin{array}{l}-0.047 \\
(0.038)\end{array}$ & & \\
\hline Charged illegal by 1980 & $\begin{array}{c}0.018 \\
(0.016)\end{array}$ & & \\
\hline Age first marriage & $\begin{array}{c}-0.051 * * * \\
(0.010)\end{array}$ & & \\
\hline Race: Hispanic & $\begin{array}{c}0.018 \\
(0.016)\end{array}$ & & \\
\hline Race: black & $\begin{array}{l}-0.023 \\
(0.023)\end{array}$ & & \\
\hline One sibling & & $\begin{array}{c}0.004 \\
(0.055)\end{array}$ & $\begin{array}{c}0.066 * * * \\
(0.022)\end{array}$ \\
\hline Two siblings & & $\begin{array}{c}0.043 \\
(0.053)\end{array}$ & $\begin{array}{c}0.092 * * * \\
(0.021)\end{array}$ \\
\hline Three siblings & & $\begin{array}{c}0.058 \\
(0.053)\end{array}$ & $\begin{array}{c}0.120^{* * *} * \\
(0.021)\end{array}$ \\
\hline Four or more siblings & & $\begin{array}{c}0.102^{* *} \\
(0.052)\end{array}$ & $\begin{array}{c}0.231 * * * \\
(0.021)\end{array}$ \\
\hline First intercourse before 16 & & $\begin{array}{c}-0.130 * * * \\
(0.037)\end{array}$ & $\begin{array}{c}0.458 * * * \\
(0.015)\end{array}$ \\
\hline First intercourse between 16 and 18 & & $\begin{array}{c}-0.120^{* * * *} \\
(0.033)\end{array}$ & $\begin{array}{c}0.265^{* * *} \\
(0.013)\end{array}$ \\
\hline First intercourse after 18 & & $\begin{array}{l}-0.050 \\
(0.035)\end{array}$ & $\begin{array}{c}0.124 * * * \\
(0.014)\end{array}$ \\
\hline Constant & $\begin{array}{c}-1.693 * * * \\
(0.379)\end{array}$ & $\begin{array}{c}-4.566^{* * *} \\
(0.104)\end{array}$ & $\begin{array}{c}-1.236 * * * \\
(0.041)\end{array}$ \\
\hline Individual Random effects & YES & & \\
\hline Observations & 45441 & 45441 & 45441 \\
\hline Number of respondents & 5574 & 5574 & 5574 \\
\hline
\end{tabular}

Notes: For the first stage of regressions only the estimates of the coefficients on the instruments are shown for the sake of concision. All columns include year and cohort dummies. $* * *$ Significant at the $1 \%$ level, ** Significant at the $5 \%$ level, * Significant at the $10 \%$ level. 
Table 13- Results of estimation of a Probit Model of Divorce.

(Sample of Respondents Over Age 21 at First Marriage)

(Dependent Variable: Risk of Marital Dissolution. Probit Model)

\begin{tabular}{|c|c|c|c|}
\hline & $\begin{array}{l}\text { IV model } \\
\text { (6) Divorce } \\
\text { outcome }\end{array}$ & $\begin{array}{c}\text { First Stage } \\
\text { Children No. } \\
\text { Within }\end{array}$ & $\begin{array}{c}\text { First Stage } \\
\text { Children No. } \\
\text { Before }\end{array}$ \\
\hline Number children conceived within marriage ${ }^{t}$ & $\begin{array}{c}-0.012 * * * \\
(0.001)\end{array}$ & & \\
\hline Number children conceived before marriage ${ }^{\dagger}$ & $\begin{array}{c}0.007 * * * \\
(0.002)\end{array}$ & & \\
\hline Man & $\begin{array}{c}0.054^{* *} \\
(0.026)\end{array}$ & & \\
\hline Age & $\begin{array}{c}0.368 * * * \\
(0.047)\end{array}$ & & \\
\hline Age squared & $\begin{array}{c}-0.004 * * * \\
(0.001)\end{array}$ & & \\
\hline Wife five years older & $\begin{array}{c}-0.119^{*} \\
(0.071)\end{array}$ & & \\
\hline Husband five years older & $\begin{array}{c}0.077 * * * \\
(0.029)\end{array}$ & & \\
\hline Highest education: lowest level & $\begin{array}{c}-0.130^{*} \\
(0.078)\end{array}$ & & \\
\hline Highest education: high school level & $\begin{array}{c}0.026 \\
(0.047)\end{array}$ & & \\
\hline Highest education: college level & $\begin{array}{l}0.091 * * \\
(0.038)\end{array}$ & & \\
\hline Highest education spouse: lowest level & $\begin{array}{l}-0.077 \\
(0.061)\end{array}$ & & \\
\hline Highest education spouse: high school level & $\begin{array}{l}-0.065 \\
(0.042)\end{array}$ & & \\
\hline Highest education spouse: college level & $\begin{array}{l}-0.014 \\
(0.039)\end{array}$ & & \\
\hline Father in household in 1979 & $\begin{array}{l}-0.022 \\
(0.030)\end{array}$ & & \\
\hline Without father figure in 1979 & $\begin{array}{c}-0.303 * * * \\
(0.103)\end{array}$ & & \\
\hline Charged illegal by 1980 & $\begin{array}{c}0.067 \\
(0.043)\end{array}$ & & \\
\hline Age first marriage & $\begin{array}{c}-0.136^{* * *} \\
(0.016)\end{array}$ & & \\
\hline Race: Hispanic & $\begin{array}{c}0.051 \\
(0.038)\end{array}$ & & \\
\hline Race: black & $\begin{array}{c}-0.352 * * * \\
(0.082)\end{array}$ & & \\
\hline Multiple birth & & $\begin{array}{c}0.614 * * * \\
(0.024)\end{array}$ & $\begin{array}{c}0.176^{* * *} \\
(0.017)\end{array}$ \\
\hline One sibling & & $\begin{array}{c}0.020 \\
(0.025)\end{array}$ & $\begin{array}{c}0.069 * * * \\
(0.019)\end{array}$ \\
\hline Two siblings & & $\begin{array}{c}0.083 * * * \\
(0.025)\end{array}$ & $\begin{array}{c}0.099 * * * \\
(0.018)\end{array}$ \\
\hline Three siblings & & $\begin{array}{c}0.113 * * * \\
(0.025)\end{array}$ & $\begin{array}{c}0.111 * * * \\
(0.018)\end{array}$ \\
\hline Four or more siblings & & $\begin{array}{c}0.177 * * * \\
(0.024)\end{array}$ & $\begin{array}{c}0.189 * * * \\
(0.018)\end{array}$ \\
\hline First intercourse before 16 & & $\begin{array}{c}-0.081^{* * *} * \\
(0.018)\end{array}$ & $\begin{array}{c}0.349 * * * \\
(0.013)\end{array}$ \\
\hline First intercourse between 16 and 18 & & $\begin{array}{c}-0.099 * * * \\
(0.015)\end{array}$ & $\begin{array}{c}0.202 * * * \\
(0.011)\end{array}$ \\
\hline First intercourse after 18 & & $\begin{array}{l}-0.016 \\
(0.016)\end{array}$ & $\begin{array}{c}0.097 * * * \\
(0.012)\end{array}$ \\
\hline Constant & $\begin{array}{c}-4.785 * * * \\
(0.490)\end{array}$ & $\begin{array}{c}-3.773 * * * \\
(0.102)\end{array}$ & $\begin{array}{c}-1.142 * * * \\
(0.074)\end{array}$ \\
\hline Individual Random effects & YES & & \\
\hline Observations & 45441 & 45441 & 45441 \\
\hline Number of respondents & 5574 & 5574 & 5574 \\
\hline
\end{tabular}

Notes: For the first stage of regressions only the estimates of the coefficients on the instruments are shown for the sake of concision. All columns include year and cohort dummies. *** Significant at the $1 \%$ level, ** Significant at the $5 \%$ level, * Significant at the $10 \%$ level. Marginal estimates are shown. 
Table 14 - Results of estimation of the model: Presence of children

(Sample of Respondents Over Age 21 at First Marriage)

(Dependent Variable: Risk of Marital Dissolution. Linear Probability Model)

\begin{tabular}{|c|c|c|c|}
\hline & $\begin{array}{l}\text { IV model } \\
\text { (7) Divorce } \\
\text { outcome }\end{array}$ & $\begin{array}{c}\text { First Stage } \\
\text { Any Children } \\
\text { Within }\end{array}$ & $\begin{array}{c}\text { First Stage } \\
\text { Any Children } \\
\text { Before }\end{array}$ \\
\hline Presence of children conceived within marriage & $\begin{array}{c}-0.794 * * * \\
(0.185)\end{array}$ & & \\
\hline Presence of children conceived before marriage & $\begin{array}{c}0.198 * * * \\
(0.064)\end{array}$ & & \\
\hline Man & $\begin{array}{c}0.004 \\
(0.011)\end{array}$ & & \\
\hline Age & $\begin{array}{c}0.176 * * * \\
(0.035)\end{array}$ & & \\
\hline Age squared & $\begin{array}{c}-0.002 * * * \\
(0.000)\end{array}$ & & \\
\hline Wife five years older & $\begin{array}{l}-0.067^{*} \\
(0.037)\end{array}$ & & \\
\hline Husband five years older & $\begin{array}{c}0.007 \\
(0.012)\end{array}$ & & \\
\hline Highest education: lowest level & $\begin{array}{c}0.007 \\
(0.023)\end{array}$ & & \\
\hline Highest education: high school level & $\begin{array}{l}-0.001 \\
(0.015)\end{array}$ & & \\
\hline Highest education: college level & $\begin{array}{l}-0.004 \\
(0.012)\end{array}$ & & \\
\hline Highest education spouse: lowest level & $\begin{array}{c}0.014 \\
(0.016)\end{array}$ & & \\
\hline Highest education spouse: high school level & $\begin{array}{l}-0.014 \\
(0.012)\end{array}$ & & \\
\hline Highest education spouse: college level & $\begin{array}{l}-0.008 \\
(0.010)\end{array}$ & & \\
\hline Father in household in 1979 & $\begin{array}{c}0.001 \\
(0.013)\end{array}$ & & \\
\hline Without father figure in 1979 & $\begin{array}{l}-0.047 \\
(0.044)\end{array}$ & & \\
\hline Charged illegal by 1980 & $\begin{array}{c}0.011 \\
(0.019)\end{array}$ & & \\
\hline Age first marriage & $\begin{array}{c}-0.049 * * * \\
(0.010)\end{array}$ & & \\
\hline Race: Hispanic & $\begin{array}{c}0.022 \\
(0.018)\end{array}$ & & \\
\hline Race: black & $\begin{array}{l}-0.029 \\
(0.027)\end{array}$ & & \\
\hline Multiple birth & & $\begin{array}{c}0.072 * * * \\
(0.031)\end{array}$ & $\begin{array}{c}0.045^{* * *} \\
(0.013)\end{array}$ \\
\hline One sibling & & $\begin{array}{c}0.015 \\
(0.030)\end{array}$ & $\begin{array}{c}0.057 * * * \\
(0.012)\end{array}$ \\
\hline Two siblings & & $\begin{array}{c}0.022 \\
(0.030)\end{array}$ & $\begin{array}{c}0.057 * * * \\
(0.012)\end{array}$ \\
\hline Three siblings & & $\begin{array}{c}0.036 \\
(0.029)\end{array}$ & $\begin{array}{c}0.096 * * * \\
(0.012)\end{array}$ \\
\hline Four or more siblings & & $\begin{array}{c}0.061 * * \\
(0.028)\end{array}$ & $\begin{array}{c}0.141 * * * \\
(0.012)\end{array}$ \\
\hline First intercourse before 16 & & $\begin{array}{c}-0.057 * * * \\
(0.020)\end{array}$ & $\begin{array}{c}0.227 * * * \\
(0.008)\end{array}$ \\
\hline First intercourse between 16 and 18 & & $\begin{array}{c}-0.049 * * * \\
(0.018)\end{array}$ & $\begin{array}{c}0.155 * * * \\
(0.007)\end{array}$ \\
\hline First intercourse after 18 & & $\begin{array}{c}-0.045^{* *} \\
(0.019)\end{array}$ & $\begin{array}{c}0.056^{* * *} \\
(0.008)\end{array}$ \\
\hline Constant & $\begin{array}{c}-1.644 * * * \\
(0.345)\end{array}$ & $\begin{array}{c}-1.835^{* * * *} \\
(0.057)\end{array}$ & $\begin{array}{c}-0.409 * * * \\
(0.023)\end{array}$ \\
\hline Individual Random effects & YES & & \\
\hline Observations & 45441 & 45441 & 45441 \\
\hline Number of respondents & 5574 & 5574 & 5574 \\
\hline
\end{tabular}

Notes: The Presence of children conceived within (or before) first marriage is a dummy variable that takes value 1 if the respondent has at least one child conceived within (or before) first marriage, and zero otherwise. For the first stage of regressions only the estimates of the coefficients on the instruments are shown for the sake of concision. All columns include year and cohort dummies. *** Significant at the $1 \%$ level, ** Significant at the $5 \%$ level, * Significant at the $10 \%$ level. 
Table 15 - Results of estimation of the model.

(Sample of All Respondents Regardless of Age at First Marriage)

(Dependent Variable: Risk of Marital Dissolution. Linear Probability Models)

\begin{tabular}{|c|c|c|c|}
\hline & $\begin{array}{l}\text { IV model } \\
\text { (8) Divorce } \\
\text { outcome }\end{array}$ & $\begin{array}{c}\text { First Stage } \\
\text { Children No. } \\
\text { Within }\end{array}$ & $\begin{array}{c}\text { First Stage } \\
\text { Children No. } \\
\text { Before }\end{array}$ \\
\hline Number children conceived within marriage & $\begin{array}{c}-0.169 * * * \\
(0.021)\end{array}$ & & \\
\hline Number children conceived before marriage & $\begin{array}{c}0.128 * * * \\
(0.017)\end{array}$ & & \\
\hline Man & $\begin{array}{l}-0.005 \\
(0.005)\end{array}$ & & \\
\hline Age & $\begin{array}{c}0.076 * * * \\
(0.007)\end{array}$ & & \\
\hline Age squared & $\begin{array}{c}-0.001 * * * \\
(0.000)\end{array}$ & & \\
\hline Wife five years older & $\begin{array}{l}-0.001 \\
(0.014)\end{array}$ & & \\
\hline Husband five years older & $\begin{array}{c}0.013 * * \\
(0.006)\end{array}$ & & \\
\hline Highest education: lowest level & $\begin{array}{c}0.035 * * * \\
(0.011)\end{array}$ & & \\
\hline Highest education: high school level & $\begin{array}{c}0.008 \\
(0.008)\end{array}$ & & \\
\hline Highest education: college level & $\begin{array}{l}-0.001 \\
(0.006)\end{array}$ & & \\
\hline Highest education spouse: lowest level & $\begin{array}{c}-0.018 * * \\
(0.008)\end{array}$ & & \\
\hline Highest education spouse: high school level & $\begin{array}{c}-0.022 * * * \\
(0.007)\end{array}$ & & \\
\hline Highest education spouse: college level & $\begin{array}{c}-0.014 * * \\
(0.006)\end{array}$ & & \\
\hline Father in household in 1979 & $\begin{array}{l}-0.006 \\
(0.005)\end{array}$ & & \\
\hline Without father figure in 1979 & $\begin{array}{l}-0.032 * \\
(0.019)\end{array}$ & & \\
\hline Charged illegal by 1980 & $\begin{array}{c}0.027 * * * \\
(0.008)\end{array}$ & & \\
\hline Age first marriage & $\begin{array}{c}-0.031 * * * \\
(0.003)\end{array}$ & & \\
\hline Race: Hispanic & $\begin{array}{c}0.000 \\
(0.007)\end{array}$ & & \\
\hline Race: black & $\begin{array}{c}-0.040^{* * * *} \\
(0.012)\end{array}$ & & \\
\hline Multiple birth & & $\begin{array}{c}0.650 * * * \\
(0.037)\end{array}$ & $\begin{array}{c}0.317 * * * \\
(0.017)\end{array}$ \\
\hline One sibling & & $\begin{array}{l}-0.015 \\
(0.035)\end{array}$ & $\begin{array}{l}0.041 * * \\
(0.016)\end{array}$ \\
\hline Two siblings & & $\begin{array}{c}0.040 \\
(0.034)\end{array}$ & $\begin{array}{c}0.071 * * * \\
(0.016)\end{array}$ \\
\hline Three siblings & & $\begin{array}{l}0.057^{*} \\
(0.034)\end{array}$ & $\begin{array}{c}0.089 * * * \\
(0.016)\end{array}$ \\
\hline Four or more siblings & & $\begin{array}{c}0.099 * * * \\
(0.033)\end{array}$ & $\begin{array}{c}0.167 * * * \\
(0.015)\end{array}$ \\
\hline First intercourse before 16 & & $\begin{array}{c}-0.119 * * * \\
(0.026)\end{array}$ & $\begin{array}{c}0.446 * * * \\
(0.012)\end{array}$ \\
\hline First intercourse between 16 and 18 & & $\begin{array}{c}-0.124 * * * \\
(0.024)\end{array}$ & $\begin{array}{c}0.265^{* * *} * \\
(0.011)\end{array}$ \\
\hline First intercourse after 18 & & $\begin{array}{c}-0.083 * * * \\
(0.026)\end{array}$ & $\begin{array}{c}0.121^{* * *} \\
(0.012)\end{array}$ \\
\hline Constant & $\begin{array}{r}-0.497 * * * \\
(0.063)\end{array}$ & $\begin{array}{c}-2.855^{* * * *} \\
(0.070)\end{array}$ & $\begin{array}{c}1.133 * * * \\
(0.033)\end{array}$ \\
\hline Individual Random effects & YES & & \\
\hline Observations & 68,734 & 68,734 & 68,734 \\
\hline Number of respondents & 8,224 & 8,224 & 8,224 \\
\hline
\end{tabular}

Notes: For the first stage of regressions only the estimates of the coefficients on the instruments are shown for the sake of concision. All columns include year and cohort dummies. $* * *$ Significant at the $1 \%$ level, $* *$ Significant at the $5 \%$ level, $*$ Significant at the $10 \%$ level. 


\section{APPENDIX}

Appendix Table A - Definition of Variables

(Source: NLSY79)

\begin{tabular}{|c|c|}
\hline Variable & Definition \\
\hline \multicolumn{2}{|l|}{ Dependent Variable } \\
\hline Divorce & This variable takes value 0 while the interviewee is married, and value 1 the year before the divorce occurs. \\
\hline \multicolumn{2}{|l|}{ Variables of Interest } \\
\hline Children conceived within marriage & Number of children conceived within first marriage. \\
\hline Children conceived before marriage & Number of children conceived before first marriage. \\
\hline Children conceived within marriage aged $0-2$ & Number of children conceived within first marriage who are aged $0-2$. \\
\hline Children conceived within marriage aged 3-9 & Number of children conceived within first marriage who are aged 3-9. \\
\hline Children conceived within marriage aged $>=10$ & Number of children conceived within first marriage who are aged 10 or more. \\
\hline Children conceived before marriage aged $0-2$ & Number of children conceived before first marriage who are aged $0-2$. \\
\hline Children conceived before marriage aged 3-9 & Number of children conceived before first marriage who are aged 3-9. \\
\hline Children conceived before marriage aged $>=10$ & Number of children conceived before first marriage who are aged 10 or more. \\
\hline Presence children conceived within marriage & This variables takes value 0 when there are not children conceived within marriage, and 1 otherwise \\
\hline Presence children conceived before marriage & This variables takes value 0 when there are not children conceived before marriage, and 1 otherwise \\
\hline \multicolumn{2}{|l|}{ Control Variables } \\
\hline Man & This variable takes value 0 for women and value 1 for men. \\
\hline Age & Variable indicating the age of interviewee. \\
\hline Age squared & Variable indicating the square of the age of interviewee. \\
\hline Wife five years older & This variable takes value 1 if the wife is, at least, five years older than her husband and 0 otherwise. \\
\hline Husband five years older & This variable takes value 1 if the husband is, at least, five years older than his wife and 0 otherwise. \\
\hline Same age & This variable takes value 1 if there is an age gap between spouses of less than five years and 0 otherwise. \\
\hline Highest education: lowest level & This variable takes value 1 if the highest level of education of the interviewee is lower than $12^{\text {th }}$ grade and 0 otherwise. \\
\hline Highest education: high school level & This variable takes value 1 if the highest level of education of the interviewee is the $12^{\text {th }}$ grade (completed high school) and 0 otherwise. \\
\hline Highest education: college level & This variable takes value 1 if the highest level of education of the interviewee is between the first and the third year of college and 0 otherwise. \\
\hline Highest education: more than college level & This variable takes value 1 if the highest level of education of the interviewee is the fourth year of college or more and 0 otherwise. \\
\hline Highest education spouse: lowest level & This variable takes value 1 if the highest level of education of the interviewee's spouse is lower than $12^{\text {th }}$ grade and 0 otherwise. \\
\hline Highest education spouse: high school level & $\begin{array}{l}\text { This variable takes value } 1 \text { if the highest level of education of the interviewee's spouse is the } 12^{\text {th }} \text { grade (completed high school) and } 0 \\
\text { otherwise. }\end{array}$ \\
\hline Highest education spouse: college level & $\begin{array}{l}\text { This variable takes value } 1 \text { if the highest level of education of the interviewee's spouse is between the first and the third year of college and } 0 \\
\text { otherwise. }\end{array}$ \\
\hline Highest education spouse: more than college level & This variable takes value 1 if the highest level of education of the interviewee's spouse is the fourth year of college or more and 0 otherwise. \\
\hline Father in household in 1979 & This variable takes value 1 if respondent's father or stepfather is in household in 1979 and 0 otherwise. \\
\hline Father out household in 1979 & This variable takes value 1 if respondent's father or stepfather is not in household in 1979 and 0 otherwise. \\
\hline Without father figure in 1979 & This variable takes value 1 if respondent has no father figure in 1979 and 0 otherwise. \\
\hline Charged illegal by 1980 & This variable takes value 1 if respondent has ever been charged with illegal activity, excluding minor traffic offenses, by 1980 and 0 otherwise. \\
\hline
\end{tabular}


Age at first marriage

Race: Hispanic

Race: black

Race: other

Region FE

Cohort FE

Family income indicator

Family income indicator squared

Religion raised

\section{Living urban}

Employed

Spouse employed

Same education

Respondent more educated than spouse

Respondent less educated than spouse

\section{Instrumental Variables}

No siblings

One sibling

Two siblings

Three sibling

Four or more siblings

Multiple birth

Intimate relations before turning 16

First Intimate relations between 16 and 18 years old

First Intimate relation after 18 years old

No Intimate relations by 1983-1985
Variable indicating the age of respondent when first marriage began.

This variable takes value 1 if respondent's race is hispanic and 0 otherwise.

This variable takes value 1 if respondent's race is black and 0 otherwise.

This variable takes value 1 if respondent's race is other than black or hispanic and 0 otherwise

Dummy variables for the region of residence (North East (omitted), North Central, South, and West).

Dummy variables for the cohort of respondent (from 1957 to 1964)

Variable that relates the total net family income and the number and age of household members.

This variable is the square of the previous indicator.

Dummy variables for the religion under which respondent was raised (protestant, roman catholic, jewish, other religion, and no religion (omitted)).

This variable takes value 1 if respondent's current residence is urban and 0 otherwise.

This variable takes value 1 if respondent's employment status is employed and 0 otherwise.

This variable takes value 1 if respondent's spouse's employment status is employed and 0 otherwise.

This variable takes value 1 if respondent's education is the same as his/her spouse and 0 otherwise.

This variable takes value 1 if respondent's education is higher than his/her spouse and 0 otherwise.

This variable takes value 1 if respondent's education is lower than his/her spouse and 0 otherwise.

This variable takes value 1 if respondent has no siblings and 0 otherwise.

This variable takes value 1 if respondent has one sibling and 0 otherwise.

This variable takes value 1 if respondent has two siblings and 0 otherwise.

This variable takes value 1 if respondent has three siblings and 0 otherwise.

This variable takes value 1 if respondent has four or more siblings and 0 otherwise.

This variable takes value 1 if respondent has experienced a multiple birth during first marriage and 0 otherwise.

This variable takes value 1 if respondent had his/her first sexual intercourse before 16 years old.

This variable takes value 1 if respondent had his/her first sexual intercourse between 16 and 18 years old

This variable takes value 1 if respondent had his/her first sexual intercourse after 18 years old.

This variable takes value 1 if respondent had not had any Intimate relations by 1983-1985. 